\title{
Ecological correlates of crop yield growth and interannual yield variation at a global scale
}

\author{
Gabriela Gleiser ${ }^{1}$, Nicolay Leme da Cunha ${ }^{1}$, Agustín Sáez ${ }^{1}$, and Marcelo Adrián Aizen ${ }^{1,2}$ \\ ${ }^{1}$ Grupo de Ecología de la Polinización, Instituto de Investigaciones en Biodiversidad y Medioambiente \\ (INIBIOMA), Universidad Nacional del Comahue-CONICET, 8400 San Carlos de Bariloche, Argentina \\ ${ }^{2}$ Wissenschaftskolleg zu Berlin, 14193 Berlin, Germany \\ Correspondence: Gabriela Gleiser (gabriela.gleiser@comahue-conicet.gob.ar)
}

Received: 10 August 2020 - Revised: 21 November 2020 - Accepted: 24 November 2020 - Published: 12 January 2021

\begin{abstract}
Artificial selection and genetic engineering plus an expanding repertoire and use of agrochemical inputs have allowed a rapid and continuous increase in crop yield (i.e., volume production per unit area) over the last century, which is needed to fulfill food demands from a growing human population. However, the first signs of yield deceleration and stagnation have already been reported for some globally important crops. Therefore, the study of the drivers of yield growth and its variation is essential for directing research and policies aiming at ensuring food security in the forthcoming years. We used data on mean and variability in annual yield growth for 107 globally important crops to assess the role of environmental (i.e., climatic region) and plant intrinsic traits (i.e., type of harvested organ, pollinator dependence, and life form) as drivers of change in yield growth and its stability. We applied a comparative approach to control for biases associated with phylogenetic non-independence among crops, an approach rarely used in agronomic studies. Average yield growth and its variation were not phylogenetically structured. Yield growth decreased with increasing pollinator dependence in tree crops but not in herbaceous and shrubby crops. Interannual yield variation tended to increase with increasing pollinator dependence, and it was higher in crops from temperate regions, in those cultivated for their reproductive organs, and in tree and shrubby crops as compared with herbaceous ones. Information on ecological correlates of crop yield growth and interannual yield variation can be used in the design of more sustainable and diversified agriculture schemes.
\end{abstract}

\section{Introduction}

Human population is increasing steadily, imposing greater demands on agricultural production (Godfray et al., 2010; Foley et al., 2011). Replacement of natural habitats by croplands, advances in crop breeding programs and genetic manipulation, a wider repertoire and more intensive use of agrochemicals (including pesticides, fungicides, herbicides, and fertilizers), and a widespread adoption of increasingly sophisticated irrigation systems have all allowed a rapid growth in total crop production and crop production per unit area (i.e., crop yield) during the last century (Miflin, 2000). This growth in yield has played a central role in fulfilling increasing food demands (Tilman et al., 2002; Aizen and Harder, 2009). However, human food security depends not only on crop yield but also on its interannual variation, which can slow down yield growth (Garibaldi et al., 2011), affecting food prices and limiting people's access to a broad nutritional diet, especially in developing countries (Ray et al., 2015; Schauberger et al., 2016). Indeed, first signs of yield deceleration and stagnation have already been reported for some globally important crops (Ray et al., 2012; Iizumi et al., 2014). In this context, bringing a comparative (i.e., including several species), ecological perspective into the crop science field can be crucial to broaden our knowledge of the factors limiting crop yield. More specifically, a phylogenetically framed approach is essential to avoid statistical biases associated with phylogenetic non-independence due to shared evolutionary history among crops (Revell, 2010; Symonds and Blomberg, 2014) and, thus, to accurately identify global 
drivers and correlates of crop yield growth and growth stability (i.e., the inverse of interannual yield variation). Proper identification of these ecological drivers and correlates can be useful in designing national and supra-national policies aiming at guarantying food security in the forthcoming years. Yet, such an approach has been rarely applied in studies on crop biology (Kantar et al., 2015; Milla et al., 2015; Milla et al., 2018; Martin et al., 2019).

Plant growth depends directly on the photosynthetic rate, which is influenced by temperature as well as by light, water, and soil nutrient availability (Schulze et al., 2019). Therefore, all else being equal, tropical and subtropical crops might have higher yield growth than temperate crops because the effect of temperature on plant growth may impose an upper limit on yield in temperate zones. In addition, more pronounced daily and seasonal temperature fluctuations at higher latitudes, including the occurrence of frosts (Rodrigo, 2000), might predict lower crop yield stability. Furthermore, low solar radiation may affect soil nutrient uptake (Schauberger et al., 2016), reducing the potential for yield growth at higher latitudes. However, plant growing conditions may not be so benign in the tropics. For instance, an excess of solar radiation towards lower latitudes could be detrimental for plant development because of increasing damage risk of the photosynthetic systems (Schauberger et al., 2016; Tan et al., 2020). Also, tropical soils in humid areas suffer from intense rainfall and nutrient lixiviation, often becoming nitrogen and phosphorous limited, and thus are commonly less productive than soils in temperate regions (Santiago, 2015; Jeffery et al., 2017). Moreover, indirect climate effects, via higher weed growth and pest occurrence, can also hamper yield growth at lower latitudes (Rosenzweig and Liverman, 1992). Hence, differences in yield growth and yield variability between tropical and temperate crops, if any, might provide first cues to the relative importance of climatic factors as proximate and ultimate modulators of the growth rate in crop productivity.

Fruit and seed production rely on available resources (i.e., fixated carbon, nitrogen, phosphorous, etc.) once investment in vegetative growth and maintenance is secured (Lacey, 1986; Obeso, 2002; Weiner et al., 2009; Tuller et al., 2018); on different pollen vectors like wind, in wind-pollinated plants; and on a diversity of animal pollinators, in pollinatordependent plants (Willmer, 2011). Consequently, given the expected higher unpredictability associated with the production of reproductive organs, we might predict lower average yield growth and higher yield variability in those crops cultivated for their reproductive parts (i.e., either seeds or fruits) than in those cultivated for their vegetative parts (e.g., tubers, stems, leaves).

Among those crops that are cultivated for their reproductive parts, there is also a broad variability in pollinator dependence (Klein et al., 2007; Aizen et al., 2019), ranging from crops that are completely independent of animal pollinators (e.g., bananas, olives, walnuts, wheat) to crops that are com- pletely dependent on pollinators (e.g., cocoa, kiwi, vanilla, watermelon). Globally, $\sim 75 \%$ of the crops depend, to different degrees, on both wild and managed pollinators for seed and/or fruit quantity and/or quality maximization (Klein et al., 2007; Garibaldi et al., 2013; Rader et al., 2016). Because of evidence that wild and managed pollinator populations are declining in many regions (Potts et al., 2010) and that pollinator availability varies naturally over space and time (Horvitz and Schemske, 1990; Price et al., 2005), crops that rely more strongly on pollinators are expected to be more susceptible to pollinator shortages. Accordingly, Garibaldi et al. (2011) reported that crops that depended more heavily on pollinators had lower mean yield growth and lower yield stability. However, phylogenetic non-independence among crops was not accounted for, and the potential roles of more direct, confounded effects and interactions with associated factors were not evaluated.

Relative investment in reproduction also relates to plant growth form. Annual plants invest a large proportion of their total resource budget in reproduction during a single season, whereas shrubs and specially trees are long lived and make large investments to develop long-lasting supportive and protective tissues (Petit and Hampe, 2006; Weiner et al., 2009), even before any resources are devoted to reproduction (Harper, 1977; Kozlowski and Uchmanski, 1987). Also, fruit and seed production in long-lived plants are usually characterized by high interannual variation (i.e., masting) that is often determined by the overall plant's resource availability as affected by the environment, and possibly by intrinsic resource accumulation-depletion cycles (Bogdziewicz et al., 2019). Thus, genetic or cultivation improvements are probably reflected in faster and more constant yield growth in annual crops as compared to shrubs and trees, which have longer life cycles and more complex patterns of resource allocation (Cheplick, 2005).

Crop species sharing a common recent ancestor may also show more similar yield growth just by descent. Indeed, significant phylogenetic signal has been reported in traits related to photosynthesis and plant growth (Zheng et al., 2009). Therefore, any analysis of crop yield growth and stability involving several crops should be evaluated within a phylogenetic context. Furthermore, because environmental and plant intrinsic traits do not act independently, the evaluation of possible interactions between them is fundamental. For example, as previously mentioned, lower yield stability was reported for those crops that depend more heavily on pollinators (Garibaldi et al., 2011). However, this pattern may also depend on the region in which crops are being cultivated, as yield of pollinator-dependent crops may be more stable in the tropics due to pollinators being mostly active all year (Souza et al., 2018; Rabeling et al., 2019). Also, the effect of pollinator dependence on yield may be more important in trees than in annual plants, as the former depend more strongly on the amount and quality of the pollination service (Knight et al., 2005; Petit and Hampe, 2006; Brittain et al., 2014). 
Here, we conducted a comparative analysis of crop yield growth and its variation over a 57-year time series for more than 100 globally important crops. By applying phylogenetically explicit analyses, we assessed the influence of climatic region (i.e., tropical vs. temperate) and plant intrinsic factors (i.e., type of harvested organ, pollinator dependence, and life form) on mean annual yield growth and its variability, as well as explored possible interactions between these factors. Specifically, we predicted higher yield growth and/or yield stability in tropical/subtropical than temperate crops, in crops cultivated for their vegetative parts, in short-lived crops, and in those with reduced dependence on pollinators. Our results supported several of these expectations and revealed interesting interactions, broadening our knowledge of the ecological factors that affect crop yield growth and stability.

\section{Methods}

\subsection{Database and phylogeny construction}

Data on crop yield (hectograms/hectare) were obtained from the United Nations Food and Agriculture Organization database for 113 crops and crop items (i.e., aggregations of different species; Aizen et al., 2019; Table A1) from 1961 to 2017 (FAOSTAT, 2019). Temporal series for three crops were shorter (cassava leaves, 1990-2017; kiwi, 1970-2017; triticale, 1975-2017). With these data we estimated, for each crop, the mean yield growth, $\Delta$ yield, as

$\Delta$ yield $=\sum_{t=1}^{N-1}\left[\ln \left(\right.\right.$ yield $\left.\left._{t+1}\right)-\ln \left(\operatorname{yield}_{t}\right)\right] / N-1$,

with $t$ being a given year, $N$ the total number of years with data (i.e., 57 years for most crops, starting from 1961), and $\ln \left(\right.$ yield $\left._{t+1}\right)-\ln \left(\right.$ yield $\left._{t}\right)$ the relative yield growth rate between year $t$ and year $t+1$. Similarly, we estimated the variability in yield growth, $\mathrm{SD}(\Delta$ yield $)$, as

$\mathrm{SD}(\Delta$ yield $)$

$$
=\sqrt{\frac{\sum_{t=1}^{N-1}\left\{\left[\ln \left(\text { yield }_{t+1}\right)-\ln \left(\text { yield }_{t}\right)\right]-\Delta \text { yield }\right\}^{2}}{N-2}},
$$

with $\mathrm{SD}(\Delta$ yield $)$ being the standard deviation of $\ln \left(\operatorname{yield}_{t+1}\right)-\ln \left(\right.$ yield $\left._{t}\right)$. This measure of variability in annual yield growth is basically a linearly detrended measure of interannual variation in (log) yield (hereafter "interannual yield variation") and thus an inverse measure of yield stability. Also, even though Eq. (1) can be simplified as $\left[\ln \left(\operatorname{yield}_{2017}\right)-\ln \left(\operatorname{yield}_{1961}\right)\right] / 56$, this more complex expression reveals that Eqs. (1) and (2) depict the first (position) and second (dispersal) moments of the distribution of annual yield growth, respectively. Since both $\Delta$ yield and the $\mathrm{SD}(\Delta$ yield) are based on differences in log yields, they provide comparable relative estimates of yield growth and its variation across crops, while increasing compliance of these response variables with normal-distribution assumptions underlying the linear tests used to analyze data. Also, these two measures are unitless, as the difference between $\log$ yields is the $\log$ of their ratio. In the case of mean yield growth, $100 \cdot\left(e^{\Delta \text { yield }}-1\right)$ provides the mean annual percent increase in yield.

The crop climatic region of origin (i.e., tropical or temperate) was searched from the literature (Table A2); crops were categorized as belonging to the two main climatic regions: "tropical-subtropical" when their region of origin never exceeded $35^{\circ}$ latitude and "temperate" when their region of origin extended above $35^{\circ}$ (Jeffery et al., 2017). In general, tropical crops are being cultivated mainly in the tropics, while crops originating in temperate regions are being cultivated mainly in temperate zones (Leff et al., 2004). Even though some temperate crops like wheat are cultivated both in temperate and tropical latitudes, most of its production is accounted for by temperate countries (e.g., China, Russia, Ukraine, USA, Canada, Argentina). Similarly, a greater share of the global production of subtropical/tropical staple crops like maize and rice that are widely cultivated in temperate latitudes comes from tropical/subtropical countries or tropical/subtropical regions within countries (FAOSTAT, 2019). Therefore, we assume that crop climatic region of origin reflects the climatic region of cultivation. Also, for animalpollinated crops, optimal yields are expected in the region of origin (Garibaldi et al., 2013; Brown and Cunningham, 2019). Data on type of harvested organ (i.e., vegetative or reproductive organs) and life form (i.e., herbs, shrubs, or trees) were also obtained from the literature (Milla, 2020). Pollinator dependence data for each crop were extracted from Klein et al. (2007) and Aizen et al. (2019), the latter for crops not included in the former study, where five classes were defined: "none", for no yield reduction in the absence of pollinators; "little", for the range $0 \%-10 \%$ of yield reduction without pollinators; "modest", for the range $10 \%-30 \%$ of yield reduction; "considerable" for the range $40 \%-90 \%$ of yield reduction; and "essential", for cases where yield reduction in the absence of pollinators exceeded $90 \%$.

A synthesis-based phylogeny (i.e., a phylogeny that is obtained by sub-setting an already available mega-phylogeny) was built to represent phylogenetic relations among crops. This kind of phylogenies has proved robust to detect even weak phylogenetic signals and to be useful in community phylogenetic analyses (Li et al., 2019). The first step to obtain the synthesis-based tree involved checking crop species names to match accepted names in The Plant List (Table A1). An initial phylogeny including all checked species was then obtained using the function "phylo.maker" from the R package V.PhyloMaker, using the GBOTB.extended megaphylogeny (74531 tips) as backbone, and the option "scenario 1", which adds missing species as basal polytomies within their genera or families (Jin and Qian, 2019). Missing species were identified by comparing the focal species list 
with the tips in the mega-phylogeny. The phylogenetically closest taxa of these missing species were searched in the literature and were used as input information when running the function "phylo.maker". This procedure has been shown to improve the placement of missing taxa into the resulting phylogeny (Jin and Qian, 2019).

A phylogenetic tree with 157 tips was obtained with the methodology described above. This tree was then modified to match FAO crop items (i.e., 113 items) by collapsing those nodes that included species belonging to the same FAO items. Six FAO items (i.e., "anise, badian, fennel, and coriander", "nutmeg, mace, and cardamoms", "mangoes, mangosteens, and guavas", "green chilies and peppers", "dry chilies and peppers", and "millets") included species phylogenetically dispersed, even belonging to unrelated families (Table A1); these items were excluded from the analyses. In some cases, FAO items comprised species phylogenetically dispersed (Table A1) but that could be represented as soft polytomies including a few items (e.g., "Brassicaceae clade", which included the items "rapeseed", "mustard seed", "cauliflowers and broccoli", and "cabbages"); these cases were kept in the analyses (see Fig. A1). The clade comprising the crops "potatoes", "tomatoes", and "eggplants" was resolved according to Milla (2020).

\subsection{Phylogenetic signal and phylogenetically controlled regressions}

Phylogenetic signals in mean yield growth and interannual yield variation were calculated with Blomberg's $K$ index (Blomberg et al., 2003). This index quantifies the amount of phylogenetic signal in the data relative to a Brownian motion (BM) model of trait evolution, with $K=0$ indicating a random distribution of the trait along the phylogeny (i.e., absence of phylogenetic signal) and $K=1$ reflecting a BM pattern of trait evolution (i.e., presence of phylogenetic signal). $K$ estimates were obtained with the R package phytools (Revell, 2012), and their statistical significance was assessed by generating 10000 randomized values of $K$. Furthermore, as phylogenetic signal may vary across the phylogeny, we looked for the existence of local hotspots of phylogenetic autocorrelation by estimating local indicators of phylogenetic association scores (LIPA scores hereafter) for each crop in the phylogeny (Anselin, 1995; Keck et al., 2016). Positive LIPA scores for a given trait of interest indicate that the phylogenetic neighborhood of a focus tip in the phylogeny is more similar for that trait than expected by chance. LIPA scores and their statistical significance were obtained with the R package phylosignal, on the basis of patristic phylogenetic distances and 999 randomizations (Keck et al., 2016).

Even in the absence of phylogenetic signal in the response variables, accounting for species-shared evolutionary history is recommended in interspecific comparisons (Felsenstein, 1985; Revell, 2010). Therefore, the associations of yield growth and interannual yield variation with climatic region, type of harvested organ, pollinator dependence, and life form were evaluated by conducting phylogenetic least squares (PGLS; Paradis, 2012) regressions, which account for phylogenetic non-independence among species. Phylogenetic correlations among species are made explicit in these regressions by including a residual variance-covariance matrix, which can be constructed by assuming different evolutionary models. PGLS regressions were ran using the ape v. 5.3 (Paradis and Schliep, 2019) and nlme v 3.1-140 (Pinheiro et al., 2019) R packages, and the fit of the residuals to different evolutionary models (as available in the ape $\mathrm{R}$ package) was compared in terms of the Akaike information criterion (AIC). Following a step-up analysis strategy (West et al., 2007), mean yield growth and interannual yield variation were regressed, alternatively, against single predictors (i.e., climatic region, type of harvested organ, pollinator dependence, or crop life form) and against combinations of two predictors to account for predictor interactions and potential confounding effects (Mazer, 1989). Higher factorial designs were not analyzed due to being too incomplete and unbalanced. Also, the tree category was excluded from the "type of harvested organ + life form" combination given that only reproductive organs (i.e., fruits or seeds) are harvested from the included tree crops. Finally, the two-predictor combination "type of harvested organ + pollinator dependence" was not tested, as the development of the vegetative organs that we consume does not depend on pollination, and thus these two factors do not cross. All predictors were treated as categorical variables in the analyses; however, the existence of a linear trend was evaluated for the relations between pollinator dependence and yield growth and yield stability given that pollinator dependence itself has an increasing (or decreasing) order across categories. In these cases, the five different categories of pollinator dependency were assigned discrete values from 0 to 4 for "none", "little", "modest", "considerable", and "essential", respectively. Model-estimated means and their standard errors were calculated using the R package effects (Fox and Weisberg, 2019).

\section{Results}

Mean annual yield growth was about 0.008 (equivalent to $0.802 \% \mathrm{yr}^{-1}$ ) and highly variable across crops, ranging from an average logarithmic increase of $0.025\left(2.546 \% \mathrm{yr}^{-1}\right)$ in kiwis to a decrease in yield of $-0.037\left(-3.614 \% \mathrm{yr}^{-1}\right)$ in currants (Table A3). The most stable crop in terms of yield variation was lettuce, with an interannual variation of 0.019 , followed by sugar cane and rice $(0.020$ and 0.022 , respectively). On the contrary, the greatest interannual yield variation, 0.425, was observed in jojoba, which could relate to the quite extreme arid conditions present in the regions where it is mostly grown (Al-Obaidi et al., 2017; FAOSTAT, 2019). This crop departed clearly from the rest (about $50 \%$ more variable than Brazil nuts, 0.291, and pistachios, 0.282, 
the following most variable crops; see Fig. A2), and thus it was considered as an outlier and excluded from the analyses of the determinants of yield growth stability. Mean annual yield growth and interannual yield variation were negatively, albeit weakly correlated across crops $(r=-0.362$, $p<0.001)$. Thus, those crops with more variable yields also tended to exhibit lower yield grow rates.

Differences in crop yield growth could not be explained by crop similarity due to common ancestry, as there was no evidence of an overall phylogenetic signal in this trait $\left(K=1.426 \times 10^{-6}, p=0.331\right)$. Accordingly, only $6 \%$ of all crops, mainly belonging to the Prunus clade, were surrounded by phylogenetic neighborhoods with similar yield growths (i.e., significant local positive phylogenetic autocorrelation; Fig. A3). Phylogenetically controlled regressions showed no significant effects of climatic region or type of harvested organ on the rate of yield growth (Table A4). Yield growth tended to decrease with pollinator dependence (Table A4; linear trend contrast: $\beta=-0.017, \mathrm{SE}=0.008$, $p=0.047)$ and was about $64 \%$ and $88 \%$ lower in shrubs and trees than herbs, respectively $(\beta=-0.008, \mathrm{SE}=0.003, p=$ 0.015 for shrubs; and $\beta=-0.011, \mathrm{SE}=0.002, p<0.001$ for trees). However, a significant statistical interaction between pollinator dependence and life form (Table A4) indicated that the reduction in yield growth associated with pollinator dependence is only evident in tree crops (Fig. 1; linear contrasts with $\beta=0.005, \mathrm{SE}=0.011, p=0.642$ for herbs; $\beta=0.028, \mathrm{SE}=0.023, p=0.225$ for shrubs; and $\beta=-0.037, \mathrm{SE}=0.013, p=0.006$ for trees). Therefore, tree crops that are highly dependent on pollinators showed, on average, the lowest growth in yield.

Crop similarity due to common ancestry was not reflected in yield stability, as there was no evidence of phylogenetic signal in interannual yield variation globally $(K=6.479 \times$ $\left.10^{-7}, p=0.651\right)$. Local phylogenetic autocorrelation was detected but involved only ca. $10 \%$ of all crops, with significant LIPA positive scores detected in all members of the [Amaryllidaceae + Asparagaceae] clade as well as in other six phylogenetically dispersed crops (Fig. A3). Interannual yield variation was $33 \%$ higher in temperate than tropical crops $(\beta=0.027, \mathrm{SE}=0.011, p=0.020$; Fig. $2 \mathrm{a})$ and $65 \%$ higher in those crops cultivated for consumption of their reproductive organs than in crops cultivated for their vegetative organs $(\beta=0.039, \mathrm{SE}=0.015, p=0.010 ;$ Fig. $2 \mathrm{~b})$. These results were not confounded by the inclusion of tree crops that are only harvested for their seeds or fruits, as a significant difference in yield variability persisted after excluding trees and controlling for the remaining growth forms (Table A4; Fig. A4). Interannual yield variation tended to increase with increasing pollinator dependence (Fig. 2c; linear contrast: $\beta=0.105, \mathrm{SE}=0.048, p=0.032$ ), despite the overall test not being statistically significant (Table A4). Crops highly dependent on animal pollination were, on average, about $50 \%$ more variable in yield that those that do not depend, or depend little, on pollinators. Finally, in- terannual yield variation was $37 \%$ higher in trees than in herbaceous crops $(\beta=0.030, \mathrm{SE}=0.013, p=0.023)$, with shrubs showing values of yield variability closer to trees than to herbs (Fig. 2d).

\section{Discussion}

Increasing crop yield to fulfill the continuous rising food demands from a growing human population, while minimizing the impact on natural ecosystems, is one the main challenges of modern agriculture (Tilman, 1999; Tilman et al., 2002; Foley et al., 2011; Bommarco et al., 2013). Genetic and management innovations have boosted a steady increase in crop yield since the middle of the last century (Evenson and Gollin, 2003; Garibaldi et al., 2011; Hatfield and Walthall, 2015). However, the first signs of yield deceleration and stagnation have already been reported for some globally important crops (Ray et al., 2012; Kucharik et al., 2020). Under this scenario, an ecological perspective can be crucial to broaden our knowledge of the factors affecting crop yield growth. By applying a comparative approach, here we uncovered the influence of environmental and plant intrinsic traits on average yield growth and on its interannual variation. Specifically, we found that yield growth decreased with increasing pollinator dependence in tree crops but not in herbaceous and shrubby crops. Interannual yield variation was higher in crops from temperate regions, in those cultivated for their reproductive organs, and in tree and shrubby crops as compared with herbaceous ones, and it tended to increase with increasing pollinator dependence. Unexpectedly, average yield growth and its variation were not phylogenetically structured. Therefore, our results revealed new and intriguing patterns, which we discuss below.

There was no evidence that climatic region was related to yield growth, with temperate crops exhibiting similar mean growth rates to tropical-subtropical crops $\left(0.72 \% \mathrm{yr}^{-1}\right.$ vs. $\left.0.83 \% \mathrm{yr}^{-1}\right)$. Under the assumption that the climatic region where a crop (or its ancestors) originated reflects the climatic conditions where the crop is most commonly cultivated, higher temperature and an overall more benign environment for plant growth in the tropics was not reflected in significantly higher rates of yield growth. As proposed in the Introduction, it might well be that more intense weed competition and, perhaps, higher herbivore pressure at low latitudes counteract the positive effect of a more benign and stable climate on crop development (Rosenzweig and Liverman, 1992). Alternatively, crop genetic and management improvements could have been more prevalent and intense among temperate crops (e.g., wheat, canola). However, this seems unlikely as several tropical-subtropical crops have also been genetically manipulated intensively and are grown industrially (e.g., soybean, rice, maize; Aizen et al., 2019). Despite no apparent differences in yield growth, we did find that interannual yield variation was lower in tropical-subtropical 

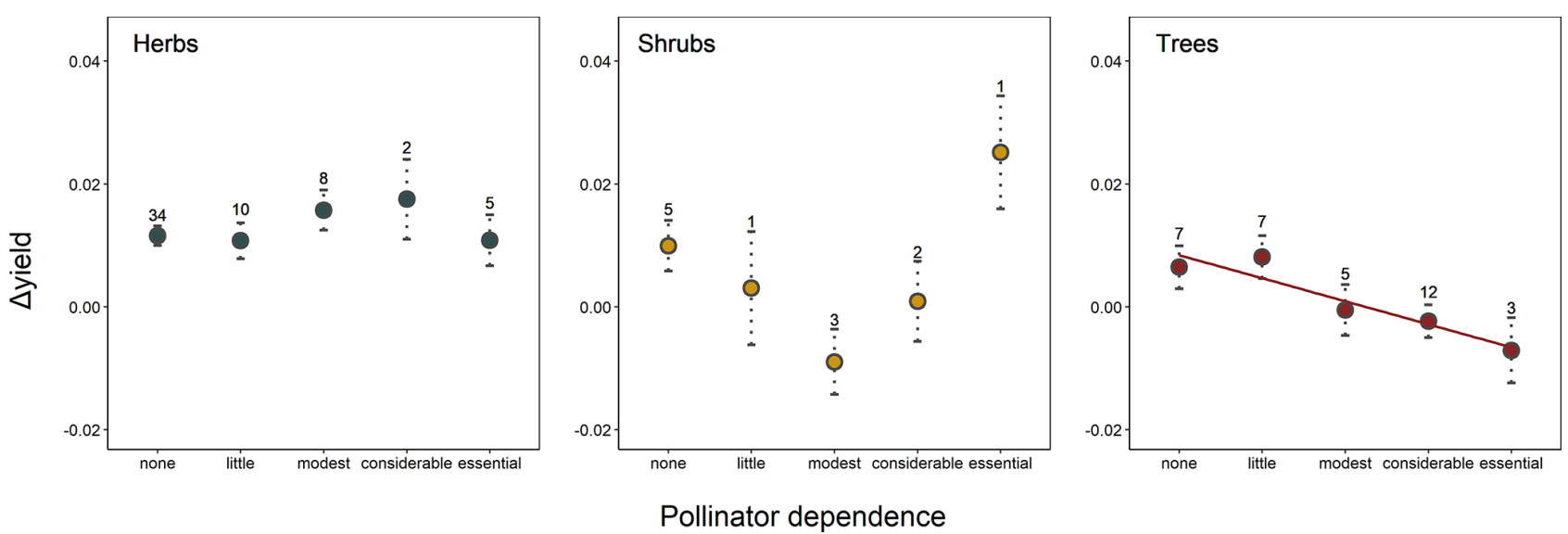

Figure 1. Joint effect of pollinator dependence and crop life form on mean yield growth ( $\Delta$ yield). The single significant linear trend found (in tree crops; see results) is indicated with a regression line. Points depict model-adjusted estimated means, while dotted lines model-adjusted standard errors. Sample sizes are shown for each category. Note that $\Delta$ yield is unitless (see Methods).

than temperate crops, probably reflecting higher climatic stability at lower latitudes. Previous studies focusing in four of the most economically important crops (i.e., wheat, maize, soybean, and rice) have identified temperature and precipitation variability as the main factors explaining yield variation (Ray et al., 2015; Schauberger et al., 2016). While water availability may limit plant growth in both zones (Kramer, 2019), temperature amplitude is greater in temperate zones, and occasional extreme temperatures may occur more frequently in these zones (e.g., occurrence of frosts; Rodrigo, 2000; Snyder and de Melo-Abreu, 2005). The stability and performance of many physiological and biochemical processes affecting plant growth - including photosynthesis, stomatal conductance, and nutrient uptake - depend on an optimal temperature range and can be disturbed by the occurrence of temperatures outside this range (Schauberger et al., 2016; Slot and Winter, 2017). Given that the greater yield variability observed among temperate crops was independent of whether the crops were harvested for their vegetative or reproductive organs (Table A4), higher yield variation in temperate regions may be explained by extreme temperatures affecting biochemical processes involved in the development of both vegetative and reproductive organs.

Yield growth seems to be independent of whether a crop is cultivated for its vegetative or for its reproductive parts. However, crops cultivated for their vegetative parts show more stable yields than those cultivated for either their fruits or seeds. This lower variation may result from the fact that investment in vegetative parts (i.e., leaves, stems, roots, tubers, rhizomes) is quintessential to plant survivorship, and even though it can be regulated, it cannot be postponed (Horvitz and Schemske, 2002; Obeso, 2002). On the contrary, variable resource availability can determine high variability in fruit and seed production among reproductive seasons in iteroparous species (Weiner et al., 2009; Hulshof et al., 2012), and even in annual plants, in which sexual reproduction in a given year can fail entirely (Kho, 2000). Besides resource availability as an intrinsic source of variability, most fruit and seed crops depend to different degrees on an external agent, either wind or insect pollinators, for pollen transfer between flowers (Klein et al., 2007). Particularly, restricted pollen transfer due to pollinator scarcity can be an important factor limiting fruit and seed set in a large fraction of wild plants and crops. In fact, pollen limitation (i.e., the failure of achieving maximum seed set as a consequence of inadequate pollination; Knight et al., 2005) affects more than a half of all crops (Aizen et al., 2008). As a consequence, pollinator availability, which is highly variable in time and space (Herrera, 1988; Price et al., 2005), can also determine high variability in yield. Agreeing with this hypothesis, we report a trend of increasing interannual yield variation with increasing dependence on animal pollination. This confirms results from previous reports (Garibaldi et al., 2011), although our conservative analysis controlled for phylogenetic non-independence among crops.

Pollen limitation has also been proposed to limit yield growth in addition to decreasing yield stability. In fact, a proposed global pollinator decline is expected to affect total agriculture production by decelerating yield growth or even decreasing the yield of pollinator-dependent crops (Aizen et al., 2008; Potts et al., 2010). Even though previous studies have reported that yield growth decreased with increasing crop pollinator dependence (Aizen et al., 2008; Garibaldi et al., 2009, 2011), these studies did not account for potentially confounding factors and phylogenetic non-independence. In particular, by accounting for growth form, we found that this trend was only apparent in trees, in which high pollinator dependence seems to hinder yield growth. In fact, several tropical-subtropical and temperate tree crops that depend to a large extent on pollinators to produce either fruits or seeds, 

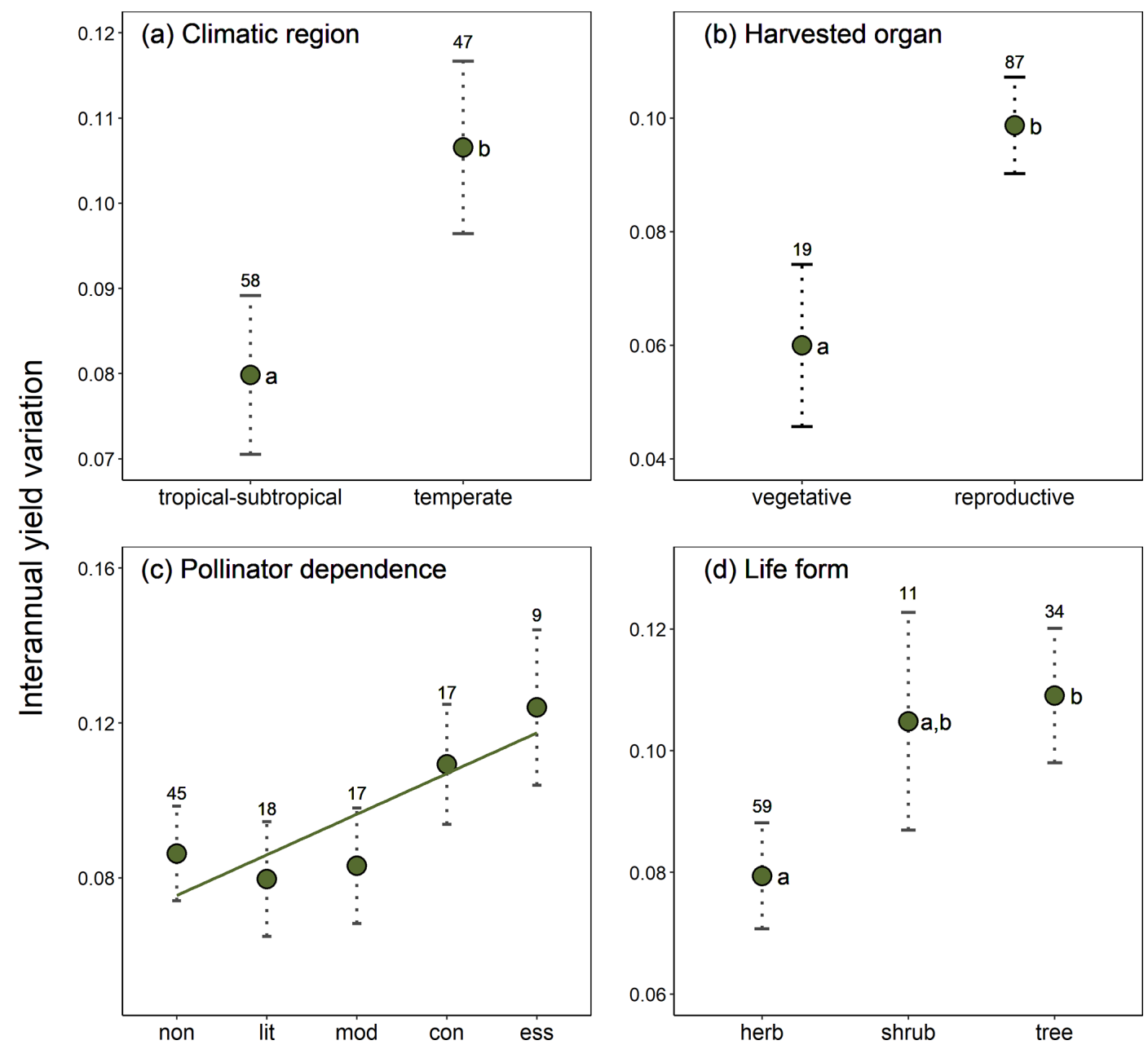

Figure 2. Effects of (a) climatic region, (b) type of harvested organ, (c) pollinator dependence, and (d) crop life form on interannual yield variation $(\operatorname{SD}(\Delta$ yield $)$ ). Model-adjusted estimated means are illustrated with points and standard errors with dotted lines. Sample sizes are shown for each category. The regression line in panel (c) illustrates the positive linear trend found for the relation between interannual yield variation and pollinator dependence (see Results). Significant differences among categories are indicated with different letters (Table A4). Pollinator dependence categories are abbreviated as "non" (none), "lit" (little), "mod" (moderate), "con" (considerable) and "ess" (essential). Note that SD ( $\Delta$ yield) is unitless (see Methods).

or even fail to produce fruits or seeds without pollinators, have shown negative growth rates during the last decades (e.g., Brazil nuts, kola nuts, cashew, plums, cherries, quinces, blueberries; Table A3), supporting the view that a global pollinator decline is affecting crop yield. However, it is puzzling that no trend for decreasing yield was observed among herbaceous crops, and apparently a concave trend was found for shrubs (Fig. 1). Several factors could explain these discrepancies. First, independent of their pollinator dependence, there seems to be lower pollen limitation in herbaceous than woody plants (Knight, 2005). Therefore, and perhaps associated with much larger floral displays and higher incidence of self-incompatibility, greater pollinator abundance is needed to maximize crop yield in trees than in herbaceous crops (Garibaldi et al., 2020). Second, hand and other forms of artificial pollination constitute a customary procedure in highly valuable herbaceous and shrubby crops like vanilla and kiwi, respectively (Arditti et al., 2009, Sáez et al., 2019), which lowers their dependence on declining insect pollinators. Although there are some accounts of fruit production based on hand pollination for highly pollinator dependent tree crops (e.g., apples in China; Partap et al., 2001; Partap and Ya, 2012), this is a highly laborious and geographically restricted procedure.

It has been proposed that reduced yield growth could be a consequence of higher variability of a crop's input resource (i.e., pollinators) via what is known as Jensen's inequality (Jensen, 1906; Ruel and Ayres, 1999), which is predicted when there is a positive but saturating response of yield with an increase in an agriculture input (Garibaldi et al., 2011). In this case, variability in an agriculture input resource is expected to be reflected in higher yield variation, resulting in 
a decrease in average yield over years. In fact, higher variability in yield associated with larger reproductive uncertainty has been proposed as an explanation of reduced yield in highly pollinator dependent crops (Garibaldi et al., 2011). Although here we report an overall negative relation between yield growth and variability, as expected due to Jensen's inequality, the interactive effects of growth form and pollinator dependence on yield growth still persisted after accounting for yield variation (Table A5). Thus, reduced yield growth in highly pollinator dependent trees can be interpreted as a direct consequence of their dependence on this external biotic input rather than of the yield uncertainty introduced by this dependence.

Lower pollen limitation in herbaceous than woody plants might also explain why in general yield growth and yield stability decreased along a gradient of crop increasing woodiness. Moreover, herbs and trees differ in the length of their life cycles, which influences the pattern of resource allocation between vegetative and reproductive structures. Life cycles are shorter in herbs, and resources are invested mainly in vegetative growth and reproduction. Trees have longer life cycles, they grow taller, and have higher costs of maintenance as resources are needed for the development of supportive and protective tissues, which reduces growth rates (Petit and Hampe, 2006). Furthermore, woody species are often characterized by a variable and synchronized reproductive behavior known as "masting", which may increase plant fitness by increasing either pollination success, seed dispersal, or offspring survival through predator satiation (Pearse et al., 2016). This reproductive strategy, although beneficial for wild plant populations, is highly undesirable in agriculture, as it can increase interannual yield variation and price peaks (Smith and Samach, 2013; Ray et al., 2015). All tree crops included in this study are being cultivated for exploitation of their fruits or seeds, and their interannual variation in yield may reflect, in addition to higher pollination limitation, yearly fluctuations in resources invested in reproduction.

Finally, it is interesting that neither mean yield growth nor its variation were conditioned by crop common ancestry in the majority of the analyzed crops. This is a meaningful finding that indicates that crop genetic and management improvements could overcome several developmental and ecological conditionings, besides those analyzed here, which may be phylogenetically structured. As a consequence, phylogenetically related crops that probably have been manipulated genetically to different extents can exhibit contrasting yield growth rates (e.g., apples vs. quinces; Table A3).

\section{Concluding remarks}

The strength of a comparative approach lies in revealing general patterns. This approach has been rarely applied in interspecific studies of crop yield, despite the need for identifying global factors limiting crop yield growth and yield sta- bility. This is of paramount importance in a context of decelerating yield growth and increasing yield variability expected under climate change (Chalinor et al., 2014, Zhao et al., 2017) and global pollinator decline (Aizen et al., 2008; Potts et al., 2010). By analyzing yield growth and interannual yield variation of more than 100 globally important crops, here we identified ecological factors associated with climate, resource allocation, and pollination limitation that affect crop yield. Despite the ultimate processes and mechanisms underlying these patterns, the ecological correlates of yield growth and yield variation detected here provide a useful starting point for establishing management guidelines for crop selection. For instance, even though pollinator-dependent tree crops have relatively high market values (Bauer and Wing, 2016), agronomic schemes based solely on the cultivation of this type of crops is a risky business because of their reduced yield growth and high interannual variability, particularly in temperate regions. In any event, the relative reduced yield growth and high yield variability of highly pollinator dependent tree crops (i.e., those in the moderate and essential categories) call for the need to apply a more active and knowledge-based pollinator management than is commonly performed today. This requires not only the management of domesticated pollinators (e.g., Apis mellifera), but also the enhancement of wild pollinators through infield and outfield strategies that involve habitat management at different spatial scales (Garibaldi et al., 2014). On the other hand, agronomic schemes based exclusively on crops cultivated for either their vegetative parts or with low levels of pollinator dependence could show adequate levels of yield growth and stability, but their production is of a poorer nutritional quality and has lower market prices than the one represented by the seeds and fruits of many pollinator-dependent crops (Gallai et al., 2009; Eilers et al., 2011). Overall, our results advocate for more diverse agriculture that involves the cultivation of different crops with different ecological features, nutritional quality, and market value at all spatial scales. In addition to contributing to increasing food security in quantitative and qualitative terms, this more diversified agriculture will ensure a more sustainable agriculture and the preservation of different ecosystem services (Aizen et al., 2019). 


\section{Appendix A}

Table A1. FAO crops/items included in the study, with their corresponding species names and family. Listed species names are accepted names according to The Plant List (TPL). Items indicated with an asterisk were not included in the analyses, as they include species phylogenetically dispersed.

\begin{tabular}{|c|c|c|}
\hline Crop name & TPL accepted names & Family \\
\hline almonds & Prunus dulcis var. amara & Rosaceae \\
\hline anise, badian, fennel, and coriander* & $\begin{array}{l}\text { Pimpinella anisum } \\
\text { Illicium verum } \\
\text { Foeniculum vulgare } \\
\text { Coriandrum sativum }\end{array}$ & $\begin{array}{l}\text { Apiaceae } \\
\text { Schisandraceae } \\
\text { Apiaceae } \\
\text { Apiaceae }\end{array}$ \\
\hline apples & Malus domestica & Rosaceae \\
\hline apricots & Prunus armeniaca & Rosaceae \\
\hline areca nuts & Areca catechu & Arecaceae \\
\hline asparagus & Asparagus officinalis & Asparagaceae \\
\hline avocados & Persea americana & Lauraceae \\
\hline Bambara beans & Vigna subterranea & Fabaceae \\
\hline bananas & $\begin{array}{l}\text { Musa } \times \text { paradisiaca } \\
\text { Musa cavendishi }\end{array}$ & $\begin{array}{l}\text { Musaceae } \\
\text { Musaceae }\end{array}$ \\
\hline barley & Hordeum distichon & Poaceae \\
\hline berries & $\begin{array}{l}\text { Rubus idaeus } \\
\text { Rubus chamaemorus } \\
\text { Rubus flagellaris } \\
\text { Rubus fruticosus (unresolved) }\end{array}$ & $\begin{array}{l}\text { Rosaceae } \\
\text { Rosaceae } \\
\text { Rosaceae } \\
\text { Rosaceae }\end{array}$ \\
\hline blueberries & Vaccinium corymbosum & Ericaceae \\
\hline Brazil nuts & Bertholletia excelsa & Lecythidaceae \\
\hline broad beans & Vicia faba & Fabaceae \\
\hline buckwheat & Fagopyrum esculentum & Polygonaceae \\
\hline cabbages & $\begin{array}{l}\text { Brassica rapa } \\
\text { Brassica oleracea }\end{array}$ & $\begin{array}{l}\text { Brassicaceae } \\
\text { Brassicaceae }\end{array}$ \\
\hline carrots & Daucus carota & Apiaceae \\
\hline cashew nuts & Anacardium occidentale & Anacardiaceae \\
\hline cashew apples & Anacardium occidentale & Anacardiaceae \\
\hline cassava & $\begin{array}{l}\text { Manihot esculenta } \\
\text { Manihot palmata }\end{array}$ & $\begin{array}{l}\text { Euphorbiaceae } \\
\text { Euphorbiaceae }\end{array}$ \\
\hline cassava leaves & $\begin{array}{l}\text { Manihot esculenta } \\
\text { Manihot palmata }\end{array}$ & $\begin{array}{l}\text { Euphorbiaceae } \\
\text { Euphorbiaceae }\end{array}$ \\
\hline castor oil seeds & Ricinus communis & Euphorbiaceae \\
\hline cauliflowers and broccoli & Brassica oleracea & Brassicaceae \\
\hline cherries & Prunus avium & Rosaceae \\
\hline chestnuts & Castanea sativa & Fagaceae \\
\hline chick peas & Cicer arietinum & Fabaceae \\
\hline
\end{tabular}


Table A1. Continued.

\begin{tabular}{|c|c|c|}
\hline Crop name & TPL accepted names & Family \\
\hline \multirow[t]{2}{*}{ chicory roots } & Cichorium intybus & Asteraceae \\
\hline & Cichorium endivia & Asteraceae \\
\hline cocoa beans & Theobroma cacao & Malvaceae \\
\hline coconuts & Cocos nucifera & Arecaceae \\
\hline \multirow[t]{3}{*}{ coffee } & Coffea arabica & Rubiaceae \\
\hline & Coffea canephora & Rubiaceae \\
\hline & Coffea liberica & Rubiaceae \\
\hline cowpeas & Vigna unguiculata & Fabaceae \\
\hline \multirow[t]{2}{*}{ cranberries } & Vaccinium macrocarpon & Ericaceae \\
\hline & Vaccinium oxycoccos & Ericaceae \\
\hline cucumbers and gherkins & Cucumis sativus & Cucurbitaceae \\
\hline \multirow[t]{2}{*}{ currants } & Ribes nigrum & Grossulariaceae \\
\hline & Ribes rubrum & Grossulariaceae \\
\hline dates & Phoenix dactylifera & Arecaceae \\
\hline \multirow[t]{9}{*}{ dry beans } & Phaseolus acutifolius & Fabaceae \\
\hline & Phaseolus coccineus & Fabaceae \\
\hline & Phaseolus lunatus & Fabaceae \\
\hline & Phaseolus vulgaris & Fabaceae \\
\hline & Vigna aconitifolia & Fabaceae \\
\hline & Vigna angularis & Fabaceae \\
\hline & Vigna mungo & Fabaceae \\
\hline & Vigna radiata & Fabaceae \\
\hline & Vigna umbellata & Fabaceae \\
\hline \multirow[t]{2}{*}{ dry chilies and peppers* } & Capsicum anпиum & Solanaceae \\
\hline & Pimenta dioica & Myrtaceae \\
\hline dry peas & Pisum sativum & Fabaceae \\
\hline dry onions & Allium cepa & Amaryllidaceae \\
\hline eggplants & Solanum melongena & Solanaceae \\
\hline figs & Ficus carica & Moraceae \\
\hline garlic & Allium sativum & Amaryllidaceae \\
\hline gooseberries & Ribes uva-crispa & Grossulariaceae \\
\hline \multirow[t]{2}{*}{ grapefruits } & Citrus paradisi & Rutaceae \\
\hline & Citrus maxima & Rutaceae \\
\hline grapes & Vitis vinifera & Vitaceae \\
\hline \multirow[t]{2}{*}{ green beans } & Vigna unguiculata & Fabaceae \\
\hline & Vigna subterranea & Fabaceae \\
\hline \multirow[t]{2}{*}{ green chilies and peppers* } & Capsicum annuиm & Solanaceae \\
\hline & Pimenta dioica & Myrtaceae \\
\hline green maize & Zea mays & Poaceae \\
\hline \multirow[t]{3}{*}{ green onions and shallots } & Allium сера & Amaryllidaceae \\
\hline & Allium ascalonicum & Amaryllidaceae \\
\hline & Allium fistulosum & Amaryllidaceae \\
\hline green peas & Pisum sativum & Fabaceae \\
\hline
\end{tabular}


Table A1. Continued.

\begin{tabular}{|c|c|c|}
\hline Crop name & TPL accepted names & Family \\
\hline groundnuts & Arachis hypogaea & Fabaceae \\
\hline hazelnuts & Corylus avellana & Betulaceae \\
\hline jojoba seeds & Simmondsia chinensis & Simmondsiaceae \\
\hline karite nuts & Vitellaria paradoxa & Sapotaceae \\
\hline kiwi & Actinidia deliciosa & Actinidiaceae \\
\hline kola nuts & $\begin{array}{l}\text { Cola nitida } \\
\text { Cola acuminata }\end{array}$ & $\begin{array}{l}\text { Malvaceae } \\
\text { Malvaceae }\end{array}$ \\
\hline leeks & $\begin{array}{l}\text { Allium ampreloprasum } \\
\text { Allium spp. }\end{array}$ & $\begin{array}{l}\text { Amaryllidaceae } \\
\text { Amaryllidaceae }\end{array}$ \\
\hline lemons and limes & $\begin{array}{l}\text { Citrus limon } \\
\text { Citrus aurantiifolia } \\
\text { Citrus medica }\end{array}$ & $\begin{array}{l}\text { Rutaceae } \\
\text { Rutaceae } \\
\text { Rutaceae }\end{array}$ \\
\hline lentils & Lens culinaris & Fabaceae \\
\hline lettuce & Lactuca sativa & Asteraceae \\
\hline linseed & Linum usitatissimum & Linaceae \\
\hline maize & Zea mays & Poaceae \\
\hline mandarins, tangerines, clementines, and satsumas & $\begin{array}{l}\text { Citrus reticulata } \\
\text { Citrus limon } \\
\text { Citrus hystrix }\end{array}$ & $\begin{array}{l}\text { Rutaceae } \\
\text { Rutaceae } \\
\text { Rutaceae }\end{array}$ \\
\hline mangoes, mangosteens, and guavas* & $\begin{array}{l}\text { Mangifera indica } \\
\text { Garcinia } \times \text { mangostana } \\
\text { Psidium guajava }\end{array}$ & $\begin{array}{l}\text { Anacardiaceae } \\
\text { Clusiaceae } \\
\text { Myrtaceae }\end{array}$ \\
\hline melons and cantaloupes & $\begin{array}{l}\text { Cucumis melo } \\
\text { Cucumis metuliferus }\end{array}$ & $\begin{array}{l}\text { Cucurbitaceae } \\
\text { Cucurbitaceae }\end{array}$ \\
\hline melonseed & Cucumis melo & Cucurbitaceae \\
\hline millet* & $\begin{array}{l}\text { Echinochloa frumentacea } \\
\text { Eleusine coracana } \\
\text { Eragrostis tef } \\
\text { Panicum miliaceum } \\
\text { Paspalum scrobiculatum } \\
\text { Pennisetum glaucum } \\
\text { Setaria italica }\end{array}$ & $\begin{array}{l}\text { Poaceae } \\
\text { Poaceae } \\
\text { Poaceae } \\
\text { Poaceae } \\
\text { Poaceae } \\
\text { Poaceae } \\
\text { Poaceae }\end{array}$ \\
\hline mustard seed & $\begin{array}{l}\text { Sinapis alba } \\
\text { Brassica nigra }\end{array}$ & $\begin{array}{l}\text { Brassicaceae } \\
\text { Brassicaceae }\end{array}$ \\
\hline nutmeg, mace, and cardamoms* & $\begin{array}{l}\text { Elettaria cardamomum } \\
\text { Myristica fragrans }\end{array}$ & $\begin{array}{l}\text { Zingiberaceae } \\
\text { Myristicaceae }\end{array}$ \\
\hline oats & Avena sativa & Poaceae \\
\hline okra & Abelmoschus esculentus & Malvaceae \\
\hline olives & Olea europaea & Oleaceae \\
\hline oranges & Citrus sinensis & Rutaceae \\
\hline palm fruit oil & Elaeis guineensis & Arecaceae \\
\hline papayas & Carica papaya & Caricaceae \\
\hline peaches and nectarines & Prunus persica & Rosaceae \\
\hline
\end{tabular}


Table A1. Continued.

\begin{tabular}{|c|c|c|}
\hline Crop name & TPL accepted names & Family \\
\hline pears & Pyrus communis & Rosaceae \\
\hline \multirow[t]{2}{*}{ pepper } & Piper nigrum & Piperaceae \\
\hline & Piper longum & Piperaceae \\
\hline \multirow[t]{2}{*}{ persimmons } & Diospyros kaki & Ebenaceae \\
\hline & Diospyros virginiana & Ebenaceae \\
\hline pigeon peas & Cajanus cajan & Fabaceae \\
\hline pineapples & Ananas comosus & Bromeliaceae \\
\hline pistachios & Pistacia vera & Anacardiaceae \\
\hline \multirow[t]{2}{*}{ plums and sloes } & Prunus domestica & Rosaceae \\
\hline & Prunus spinosa & Rosaceae \\
\hline poppy seeds & Papaver somniferum & Papaveraceae \\
\hline potatoes & Solanum tuberosum & Solanaceae \\
\hline \multirow[t]{4}{*}{ pumpkins, squash, and gourds } & Cucurbita maxima & Cucurbitaceae \\
\hline & Cucurbita argyrosperma & Cucurbitaceae \\
\hline & Cucurbita moschata & Cucurbitaceae \\
\hline & Cucurbita pepo & Cucurbitaceae \\
\hline quinces & Cydonia oblonga & Rosaceae \\
\hline quinoa & Chenopodium quinoa & Chenopodiaceae \\
\hline rapeseed & Brassica napus & Brassicaceae \\
\hline rice & Oriza spp. & Poaceae \\
\hline rye & Secale cereale & Poaceae \\
\hline safflower seeds & Carthamus tinctorius & Asteraceae \\
\hline \multirow[t]{4}{*}{ seed cotton } & Gossypium hirsutum & Malvaceae \\
\hline & Gossypium barbadense & Malvaceae \\
\hline & Gossypium arboreum & Malvaceae \\
\hline & Gossypium herbaceum & Malvaceae \\
\hline sesame seeds & Sesamum indicum & Pedaliaceae \\
\hline sorghum & Sorghum bicolor & Poaceae \\
\hline sour cherries & Prunus cerasus & Rosaceae \\
\hline soybeans & Glycine max & Fabaceae \\
\hline spinach & Spinacia oleracea & Amaranthaceae \\
\hline strawberries & Fragaria spp. & Rosaceae \\
\hline \multirow[t]{4}{*}{ string beans } & Lablab purpureus & Fabaceae \\
\hline & Phaseolus coccineus & Fabaceae \\
\hline & Phaseolus vulgaris & Fabaceae \\
\hline & Vigna unguiculata & Fabaceae \\
\hline sugar beet & Beta vulgaris & Amaranthaceae \\
\hline sugar cane & Saccharum officinarum & Poaceae \\
\hline sunflower seeds & Helianthus annuus & Asteraceae \\
\hline sweet potatoes & Ipomoea batatas & Convolvulaceae \\
\hline taro & Colocasia esculenta & Araceae \\
\hline
\end{tabular}


Table A1. Continued.

\begin{tabular}{lll}
\hline Crop name & TPL accepted names & Family \\
\hline tomatoes & Solanum lycopersicum & Solanaceae \\
\hline triticale & Triticum aestivum $\times$ Secale cereale & Poaceae \\
\hline vanilla & Vanilla planifolia & Orchidaceae \\
& Vanilla pompona & Orchidaceae \\
\hline \multirow{2}{*}{ walnuts } & Juglans regia & Juglandaceae \\
& Juglans nigra & Juglandaceae \\
& Juglans cinerea & Juglandaceae \\
\hline \multirow{2}{*}{ watermelons } & Citrullus lanatus & Cucurbitaceae \\
\hline wheat & Triticum spp. & Poaceae \\
\hline yams & Dioscorea spp. & Dioscoreaceae \\
\hline yautia & Xanthosoma sagittifolium & Araceae \\
\hline
\end{tabular}


Table A2. Bibliographical sources for the climatic region of origin of the crops included in the study.

\begin{tabular}{|c|c|c|}
\hline Crop name & Climatic region of origin & Reference \\
\hline almonds & temperate & Zeinalabedini et al. (2010), Khoury et al. (2016) \\
\hline apples & temperate & Harris et al. (2002) \\
\hline apricots & temperate & Decroocq et al. (2016) \\
\hline areca nuts & tropical-subtropical & Khoury et al. (2016) \\
\hline asparagus & temperate & Milla (2020) \\
\hline avocados & tropical-subtropical & Khoury et al. (2016) \\
\hline Bambara beans & tropical-subtropical & Milla (2020) \\
\hline bananas & tropical-subtropical & Khoury et al. (2016) \\
\hline barley & temperate & Milla (2020) \\
\hline berries & temperate & Milla (2020) \\
\hline blueberries & temperate & Milla (2020) \\
\hline Brazil nuts & tropical-subtropical & Milla (2020) \\
\hline broad beans & tropical-subtropical & Caracuta et al. (2016) \\
\hline buckwheat & tropical-subtropical & Gondola and Papp (2010) \\
\hline cabbages & tropical-subtropical & Arias et al. (2014) \\
\hline carrots & temperate & Milla (2020) \\
\hline cashew nuts & tropical-subtropical & Milla (2020) \\
\hline cashew apples & tropical-subtropical & Milla (2020) \\
\hline cassava & tropical-subtropical & Milla (2020) \\
\hline cassava leaves & tropical-subtropical & Milla (2020) \\
\hline castor oil seeds & tropical-subtropical & Khoury et al. (2016), van der Vossen and Mkamilo (2007) \\
\hline cauliflowers and broccoli & tropical-subtropical & Arias et al. (2014) \\
\hline cherries & temperate & Milla (2020) \\
\hline chestnuts & temperate & Milla (2020) \\
\hline chick peas & temperate & Milla (2020) \\
\hline chicory roots & temperate & Milla (2020) \\
\hline cocoa beans & tropical-subtropical & Milla (2020) \\
\hline coconuts & tropical-subtropical & Khoury et al. (2016), Milla (2020) \\
\hline coffee & tropical-subtropical & Khoury et al. (2016), Milla (2020) \\
\hline cowpeas & tropical-subtropical & Milla (2020) \\
\hline cranberries & temperate & Khoury et al. (2016), Milla (2020) \\
\hline cucumbers and gherkins & tropical-subtropical & Sebastian et al. (2010), Milla (2020) \\
\hline currants & temperate & Milla (2020) \\
\hline dates & tropical-subtropical & Milla (2020) \\
\hline dry peas & temperate & Milla (2020) \\
\hline dry onions & temperate & Khoury et al. (2016), Milla (2020) \\
\hline eggplants & tropical-subtropical & Milla (2020) \\
\hline figs & tropical-subtropical & Khoury et al. (2016) \\
\hline garlic & temperate & Khoury et al. (2016), Milla (2020) \\
\hline gooseberries & temperate & Milla (2020) \\
\hline grapefruits & tropical-subtropical & Milla (2020) \\
\hline grapes & temperate & Toffolatti et al. (2018), Milla (2020) \\
\hline green beans & tropical-subtropical & Milla (2020) \\
\hline green maize & tropical-subtropical & Khoury et al. (2016), Milla (2020) \\
\hline green onions and shallots & temperate & Milla (2020) \\
\hline green peas & temperate & Milla (2020) \\
\hline groundnuts & tropical-subtropical & Khoury et al. (2016), Milla (2020) \\
\hline hazelnuts & temperate & Milla (2020) \\
\hline jojoba seeds & temperate & Kumar et al. (2012) \\
\hline karite nuts & tropical-subtropical & Milla (2020) \\
\hline kiwi & tropical-subtropical & Milla (2020) \\
\hline kola nuts & tropical-subtropical & Milla (2020) \\
\hline leeks & temperate & Hirschegger et al. (2010), Milla (2020) \\
\hline lemons and limes & tropical-subtropical & Khoury et al. (2016), Wu et al. (2018) \\
\hline lentils & temperate & Milla (2020) \\
\hline lettuce & tropical-subtropical & Křístková et al. (2008) \\
\hline
\end{tabular}


Table A2. Continued.

\begin{tabular}{|c|c|c|}
\hline Crop name & Climatic region of origin & Reference \\
\hline linseed & temperate & Milla (2020) \\
\hline maize & tropical-subtropical & Khoury et al. (2016), Milla (2020) \\
\hline mandarins, tangerines, clementines, and satsumas & tropical-subtropical & Wang et al. (2018), Wu et al. (2018) \\
\hline melons and cantaloupes & tropical-subtropical & Khoury et al. (2016), Milla (2020) \\
\hline melonseed & tropical-subtropical & Khoury et al. (2016), Milla (2020) \\
\hline mustard seed & temperate & Milla (2020) \\
\hline oats & temperate & Khoury et al. (2016) Milla (2020) \\
\hline okra & tropical-subtropical & Milla (2020) \\
\hline olives & temperate & Milla (2020) \\
\hline oranges & tropical-subtropical & Wu et al. (2018) \\
\hline palm fruit oil & tropical-subtropical & Milla (2020) \\
\hline papayas & tropical-subtropical & Khoury et al. (2016), Milla (2020) \\
\hline peaches and nectarines & temperate & Faust and Timon (1995) \\
\hline pears & temperate & Milla (2020) \\
\hline pepper & tropical-subtropical & Milla (2020) \\
\hline persimmons & temperate & Guo et al. (2006), Soriano et al. (2006) \\
\hline pigeon peas & tropical-subtropical & Milla (2020) \\
\hline pineapples & tropical-subtropical & Khoury et al. (2016), Milla (2020) \\
\hline pistachios & temperate & Milla (2020) \\
\hline plums and sloes & temperate & Milla (2020) \\
\hline poppy seeds & temperate & Teteni (1995) \\
\hline potatoes & tropical-subtropical & Khoury et al. (2016), Milla (2020) \\
\hline pumpkins, squash, and gourds & tropical-subtropical & Sanjur et al. (2002), Khoury et al. (2016), Milla (2020) \\
\hline quinces & temperate & Milla (2020) \\
\hline quinoa & tropical-subtropical & Milla (2020) \\
\hline rapeseed & temperate & Milla (2020) \\
\hline rice & tropical-subtropical & Milla (2020) \\
\hline rye & temperate & Milla (2020) \\
\hline safflower seeds & tropical-subtropical & Milla (2020) \\
\hline seed cotton & tropical-subtropical & Milla (2020) \\
\hline sesame seeds & tropical-subtropical & Bedigian et al. (1985), Milla (2020) \\
\hline sorghum & tropical-subtropical & Milla (2020) \\
\hline sour cherries & temperate & Milla (2020) \\
\hline soybeans & tropical-subtropical & Guo et al. (2010), Khoury et al. (2016), Milla (2020) \\
\hline spinach & temperate & Milla (2020) \\
\hline strawberries & temperate & Khoury et al. (2016), Milla (2020) \\
\hline string beans & tropical-subtropical & Milla (2020) \\
\hline sugar beet & temperate & Milla (2020) \\
\hline sugar cane & tropical-subtropical & Khoury et al. (2016), Milla (2020) \\
\hline sunflower seeds & temperate & Khoury et al. (2016), Milla (2020) \\
\hline sweet potatoes & tropical-subtropical & Khoury et al. (2016), Milla (2020) \\
\hline taro & tropical-subtropical & Khoury et al. (2016), Milla (2020) \\
\hline tomatoes & tropical-subtropical & Khoury et al. (2016), Milla (2020) \\
\hline triticale & temperate & \\
\hline vanilla & tropical-subtropical & Khoury et al. (2016), Milla (2020) \\
\hline walnuts & temperate & Milla (2020) \\
\hline watermelons & tropical-subtropical & Chomicki and Renner (2015), Milla (2020) \\
\hline wheat & temperate & Milla $(2020)$ \\
\hline yams & tropical-subtropical & Milla (2020), APG IV. \\
\hline yautia & tropical-subtropical & Milla (2020) \\
\hline
\end{tabular}


Table A3. Mean yield growth ( $\Delta$ yield), interannual yield variation $(\operatorname{SD}(\Delta$ yield)), and mean annual percent increase in yield (\% $\Delta$ yield) for the FAO crops/items included in the study. Data were obtained from the FAOSTAT database and covered a 57-year period (from 1961 to 2017) for all but three crops (see Methods for details).

\begin{tabular}{|c|c|c|c|}
\hline Crop name & $\Delta$ yield & $\mathrm{SD}(\Delta$ yield $)$ & $\% \Delta$ yield \\
\hline almonds & 0.00217058 & 0.16500452 & 0.21729338 \\
\hline apples & 0.00948692 & 0.07662275 & 0.95320648 \\
\hline apricots & 0.00449209 & 0.1181696 & 0.45021993 \\
\hline areca nuts & 0.0120489 & 0.05365916 & 1.21217782 \\
\hline asparagus & 0.01380359 & 0.03621639 & 1.38993015 \\
\hline avocados & 0.00183314 & 0.05121231 & 0.18348198 \\
\hline Bambara beans & -0.00038776 & 0.12635301 & -0.03876825 \\
\hline bananas & 0.01139601 & 0.03171601 & 1.14611969 \\
\hline barley & 0.01533921 & 0.0740192 & 1.54574621 \\
\hline berries & 0.00193931 & 0.09090424 & 0.19411926 \\
\hline blueberries & -0.01350698 & 0.16181083 & -1.34161701 \\
\hline Brazil nuts & -0.02728997 & 0.2906871 & -2.6920963 \\
\hline broad beans & 0.014011 & 0.07798472 & 1.4109615 \\
\hline buckwheat & 0.01067132 & 0.13617233 & 1.07284578 \\
\hline cabbages & 0.00888201 & 0.04706542 & 0.89215756 \\
\hline carrots & 0.01500502 & 0.03339517 & 1.51181651 \\
\hline cashew nuts & 0.00346746 & 0.07339473 & 0.34734748 \\
\hline cashew apples & -0.00887508 & 0.18441034 & -0.88358149 \\
\hline cassava & 0.00720464 & 0.02623632 & 0.72306554 \\
\hline cassava leaves & 0.00049446 & 0.05998736 & 0.04945847 \\
\hline castor oil seeds & 0.01845184 & 0.09573532 & 1.86231314 \\
\hline cauliflowers and broccoli & 0.00458121 & 0.02600946 & 0.45917179 \\
\hline cherries & -0.01541209 & 0.1356929 & -1.52939281 \\
\hline chestnuts & -0.00720649 & 0.10026083 & -0.71805809 \\
\hline chick peas & 0.00797888 & 0.11653123 & 0.80107912 \\
\hline chicory roots & 0.01107802 & 0.16175596 & 1.113961 \\
\hline cocoa beans & 0.00886955 & 0.07294877 & 0.8909006 \\
\hline coconuts & 0.00153597 & 0.04564775 & 0.15371504 \\
\hline coffee & 0.01080565 & 0.09231583 & 1.08642432 \\
\hline cowpeas & 0.00877164 & 0.15937423 & 0.88102203 \\
\hline cranberries & 0.01529573 & 0.09702625 & 1.5413304 \\
\hline cucumbers and gherkins & 0.0243494 & 0.04007409 & 2.46482683 \\
\hline currants & -0.03681024 & 0.20700515 & -3.61409772 \\
\hline dates & -0.00401493 & 0.07389119 & -0.40068783 \\
\hline dry beans & 0.00995793 & 0.04150106 & 1.00076774 \\
\hline dry peas & 0.01278227 & 0.13759495 & 1.28643156 \\
\hline dry onions & 0.00843938 & 0.02306261 & 0.84750883 \\
\hline eggplants & 0.02062972 & 0.05014455 & 2.08439831 \\
\hline figs & 0.00658167 & 0.07525325 & 0.6603379 \\
\hline garlic & 0.02077647 & 0.03700207 & 2.09938068 \\
\hline gooseberries & 0.00699571 & 0.06086436 & 0.70202393 \\
\hline grapefruits & 0.00353658 & 0.08649643 & 0.35428455 \\
\hline grapes & 0.01507857 & 0.07408466 & 1.51928241 \\
\hline green beans & 0.0190214 & 0.03288979 & 1.92034544 \\
\hline green maize & 0.0111837 & 0.06031723 & 1.12464724 \\
\hline green onions and shallots & 0.01183165 & 0.03928078 & 1.19019227 \\
\hline green peas & 0.00517291 & 0.0380565 & 0.51863108 \\
\hline groundnuts & 0.01224044 & 0.05579314 & 1.23156561 \\
\hline hazelnuts & 0.0160642 & 0.26202516 & 1.61939188 \\
\hline jojoba seeds & 0.00849108 & 0.42483628 & 0.85272309 \\
\hline karite nuts & -0.01426026 & 0.06379342 & -1.41590673 \\
\hline kiwi & 0.02514235 & 0.1507326 & 2.54610831 \\
\hline kola nuts & -0.01630822 & 0.12361623 & -1.61759574 \\
\hline leeks & 0.00321461 & 0.04575138 & 0.3219782 \\
\hline
\end{tabular}


Table A3. Continued.

\begin{tabular}{|c|c|c|c|}
\hline Crop name & $\Delta$ yield & $\mathrm{SD}(\Delta$ yield $)$ & $\% \Delta$ yield \\
\hline lemons and limes & 0.00391987 & 0.05923242 & 0.39275624 \\
\hline lentils & 0.01395521 & 0.07720088 & 1.40530396 \\
\hline lettuce & 0.0064908 & 0.0188423 & 0.65119091 \\
\hline linseed & 0.0163961 & 0.10216615 & 1.65312496 \\
\hline maize & 0.01939543 & 0.06773364 & 1.95847432 \\
\hline mandarins, tangerines, clementines, and satsumas & 0.00813799 & 0.09846082 & 0.8171193 \\
\hline melons and cantaloupes & 0.01523815 & 0.02764863 & 1.53548469 \\
\hline melonseed & -0.00368031 & 0.16040998 & -0.3673541 \\
\hline mustard seed & 0.00968023 & 0.1905356 & 0.97272304 \\
\hline oats & 0.01205159 & 0.06566067 & 1.21244981 \\
\hline okra & 0.00297939 & 0.09356481 & 0.29838309 \\
\hline olives & -0.00870367 & 0.20172565 & -0.86658988 \\
\hline oranges & 0.00722409 & 0.05250987 & 0.72502428 \\
\hline palm fruit oil & 0.02452654 & 0.04470793 & 2.4829791 \\
\hline papayas & 0.01671554 & 0.05205554 & 1.68560251 \\
\hline peaches and nectarines & 0.00961111 & 0.06859212 & 0.96574497 \\
\hline pears & 0.00917736 & 0.09477455 & 0.92196006 \\
\hline pepper & 0.01713192 & 0.10635009 & 1.72795082 \\
\hline persimmons & -0.00738406 & 0.0861261 & -0.73568611 \\
\hline pigeon peas & 0.00305091 & 0.1511845 & 0.30555716 \\
\hline pineapples & 0.01566351 & 0.04952555 & 1.57868253 \\
\hline pistachios & 0.01615674 & 0.28230055 & 1.62879686 \\
\hline plums and sloes & -0.02221958 & 0.13529796 & -2.19745443 \\
\hline poppy seeds & 0.00457541 & 0.13960183 & 0.4585889 \\
\hline potatoes & 0.00890241 & 0.05664544 & 0.89421546 \\
\hline pumpkins, squash, and gourds & 0.01934329 & 0.04959308 & 1.95315795 \\
\hline quinces & -0.00281892 & 0.09398141 & -0.28149458 \\
\hline quinoa & 0.00565192 & 0.19193331 & 0.56679232 \\
\hline rapeseed & 0.02398523 & 0.07585527 & 2.42751895 \\
\hline rice & 0.01608759 & 0.02205044 & 1.62176955 \\
\hline rye & 0.01733697 & 0.08186681 & 1.74881273 \\
\hline safflower and seeds & 0.01148734 & 0.12901911 & 1.15535747 \\
\hline seed cotton & 0.01716008 & 0.05191093 & 1.73081567 \\
\hline sesame seeds & 0.01180364 & 0.06690349 & 1.18735767 \\
\hline sorghum & 0.00830287 & 0.07352281 & 0.8337432 \\
\hline sour cherries & -0.00531848 & 0.1607349 & -0.53043584 \\
\hline soybeans & 0.01656652 & 0.06522905 & 1.67045047 \\
\hline spinach & 0.021734 & 0.14531135 & 2.19719053 \\
\hline strawberries & 0.01905668 & 0.06263665 & 1.92394179 \\
\hline string beans & 0.01074331 & 0.04143396 & 1.08012242 \\
\hline sugar beet & 0.01743104 & 0.06127232 & 1.75838492 \\
\hline sugar cane & 0.00613899 & 0.02032183 & 0.61578703 \\
\hline sunflower seeds & 0.01013751 & 0.07956927 & 1.01890654 \\
\hline sweet potatoes & 0.0091435 & 0.06615356 & 0.91854323 \\
\hline taro & 0.000032 & 0.07881259 & 0.00322584 \\
\hline tomatoes & 0.01477903 & 0.02546481 & 1.48887824 \\
\hline triticale & 0.00891108 & 0.16885613 & 0.89508998 \\
\hline vanilla & -0.00023624 & 0.22315504 & -0.02362095 \\
\hline walnuts & 0.00222087 & 0.12323914 & 0.22233346 \\
\hline watermelons & 0.02351296 & 0.04440071 & 2.37915679 \\
\hline wheat & 0.02100839 & 0.05267996 & 2.1230618 \\
\hline yams & 0.00294095 & 0.09174646 & 0.29452742 \\
\hline yautia & 0.01490923 & 0.09241804 & 1.50209298 \\
\hline
\end{tabular}


Table A4. Analysis of variance of PGLS fitted models for (a) mean yield growth ( $\Delta$ yield) and (b) interannual yield variation (SD( $\Delta$ yield)), with climatic region, type of harvested organ, pollinator dependence, and crop life form as sources of variation. Marginal sums of squares (type III) were estimated for models with more than one source of variation by applying the R function "anova" (with the option "type = marginal") on the PGLS fitted objects. Interaction terms were only kept in the models when their inclusion increased model fit in terms of AIC $(\triangle \mathrm{AIC} \geq 2)$; all interactions between predictors not informed were statistically non-significant $(p>0.05)$. Significant tests $(p<0.05)$ are indicated in bold type.

\begin{tabular}{|c|c|c|c|c|}
\hline \multicolumn{5}{|l|}{ (a) } \\
\hline Source of variation & $\mathrm{DF}_{\text {num }}$ & $\mathrm{DF}_{\mathrm{den}}$ & $F$ & $p$ \\
\hline Climatic region & 1 & 104 & 0.240 & 0.625 \\
\hline Harvested organ & 1 & 105 & 0.323 & 0.570 \\
\hline Pollinator dependence & 4 & 102 & 2.963 & $\mathbf{0 . 0 2 3}$ \\
\hline Life form & 2 & 102 & 13.448 & $<0.001$ \\
\hline \multicolumn{5}{|l|}{ Climatic region + harvested organ } \\
\hline Climatic region & 1 & 103 & 0.287 & 0.593 \\
\hline Harvested organ & 1 & 103 & 0.377 & 0.540 \\
\hline \multicolumn{5}{|c|}{ Climatic region + pollinator dependence } \\
\hline Climatic region & 1 & 100 & 0.224 & 0.637 \\
\hline Pollinator dependence & 4 & 100 & 2.795 & $\mathbf{0 . 0 3 0}$ \\
\hline \multicolumn{5}{|l|}{ Climatic region + life form } \\
\hline Climatic region & 1 & 100 & 0.511 & 0.476 \\
\hline Life form & 2 & 100 & 13.250 & $<0.001$ \\
\hline \multicolumn{5}{|l|}{ Harvested organ + life form* } \\
\hline Harvested organ & 1 & 68 & 0.665 & 0.418 \\
\hline Life form & 1 & 68 & 8.066 & 0.006 \\
\hline \multicolumn{5}{|l|}{ Pollinator dependence + life form } \\
\hline Pollinator dependence & 4 & 90 & 0.588 & 0.672 \\
\hline Life form & 2 & 90 & 0.908 & 0.407 \\
\hline Pollinator dependence $\cdot$ life form & 8 & 90 & 2.873 & 0.007 \\
\hline
\end{tabular}


Table A4. Continued.

\begin{tabular}{|c|c|c|c|c|}
\hline \multicolumn{5}{|l|}{ (b) } \\
\hline Source of variation & $\mathrm{DF}_{\text {num }}$ & $\mathrm{DF}_{\mathrm{den}}$ & $F$ & $p$ \\
\hline Climatic region & 1 & 103 & 5.611 & 0.020 \\
\hline Harvested organ & 1 & 104 & 6.908 & 0.010 \\
\hline Pollinator dependence & 4 & 101 & 1.404 & 0.238 \\
\hline Life form & 2 & 101 & 3.035 & 0.052 \\
\hline \multicolumn{5}{|c|}{ Climatic region + harvested organ } \\
\hline Climatic region & 1 & 102 & 6.605 & 0.012 \\
\hline Harvested organ & 1 & 102 & 8.066 & 0.005 \\
\hline \multicolumn{5}{|c|}{ Climatic region + pollinator dependence } \\
\hline Climatic region & 1 & 99 & 5.841 & 0.017 \\
\hline Pollinator dependence & 4 & 99 & 1.416 & 0.234 \\
\hline \multicolumn{5}{|c|}{ Climatic region + life form } \\
\hline Climatic region & 1 & 99 & 5.894 & 0.017 \\
\hline Life form & 2 & 99 & 3.117 & 0.049 \\
\hline \multicolumn{5}{|c|}{ Harvested organ + life form $*$} \\
\hline Harvested organ & 1 & 67 & 5.649 & 0.020 \\
\hline Life form & 1 & 67 & 2.197 & 0.143 \\
\hline \multicolumn{5}{|c|}{ Pollinator dependence + life form } \\
\hline Pollinator dependence & 4 & 97 & 1.034 & 0.394 \\
\hline Life form & 2 & 97 & 2.157 & 0.121 \\
\hline
\end{tabular}

* Tree crops were not included in the analysis. 
Table A5. Analysis of variance of a PGLS fitted model constructed to assess whether the slowdown in mean yield growth found in tree crops could be explained by Jensen's inequality effect. Interannual yield variation was used as a proxy reflecting the effect of variable pollen delivery (i.e., a resource needed for seeds or fruit production) on yield growth.

\begin{tabular}{lrrrr}
\hline Source of variation & $\mathrm{DF}_{\text {num }}$ & $\mathrm{DF}_{\text {den }}$ & $F$ & $p$ \\
\hline Pollinator dependence & 4 & 88 & 0.785 & 0.538 \\
Life form & 2 & 88 & 0.079 & 0.924 \\
Interannual yield variation & 1 & 88 & 14.703 & $\mathbf{< 0 . 0 0 1}$ \\
Pollinator dependence $\cdot$ life form & 8 & 88 & 3.252 & $\mathbf{0 . 0 0 3}$ \\
\hline
\end{tabular}




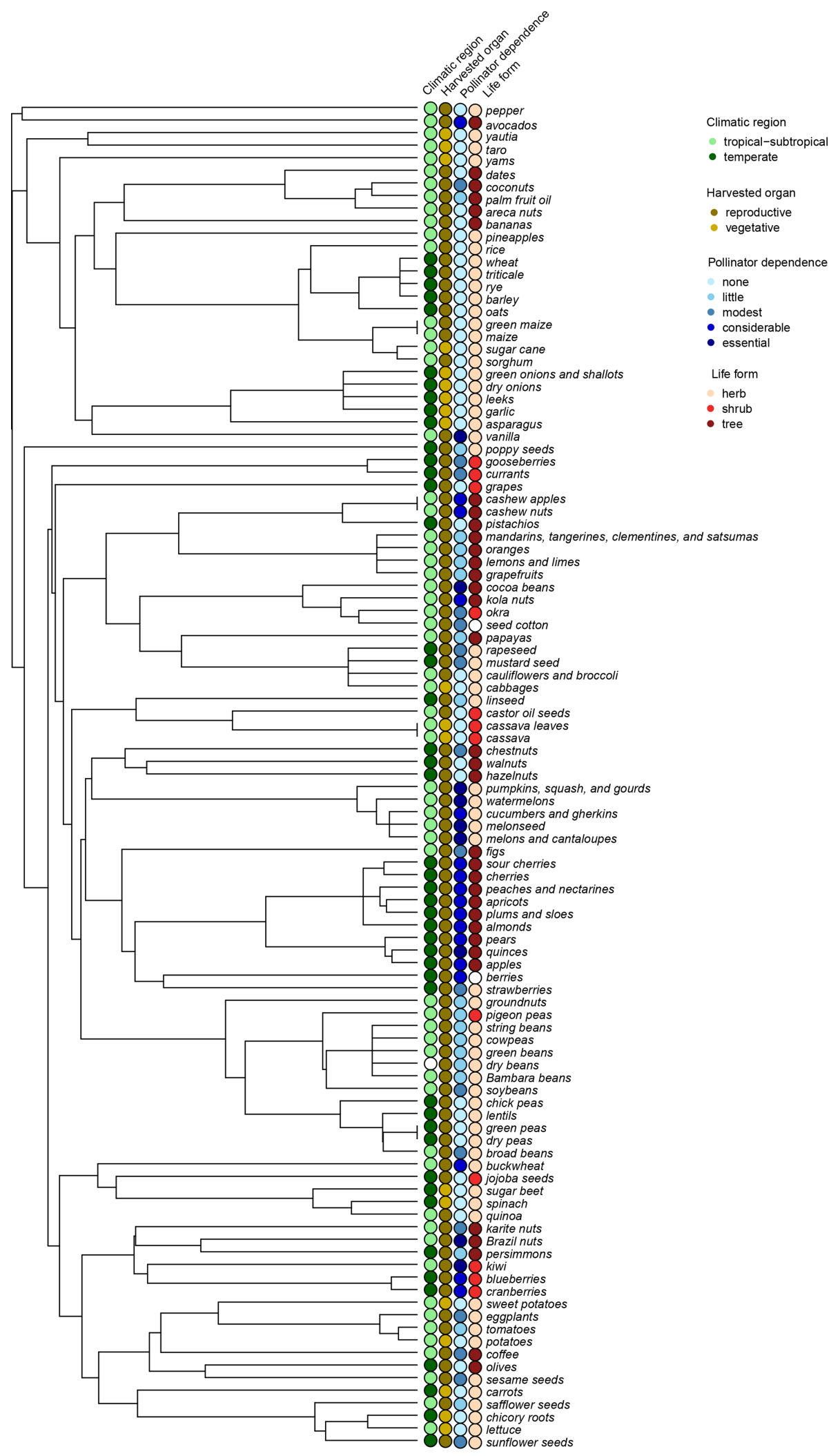

Figure A1. Phylogenetic relationships among all FAO items included in the study. Data on climatic region, harvested organ, pollinator dependence, and crop life form are indicated for each tip. Unfilled circles depict tip data that have been excluded from the analyses, as they corresponded to FAO items comprising species that differ in a given trait. 

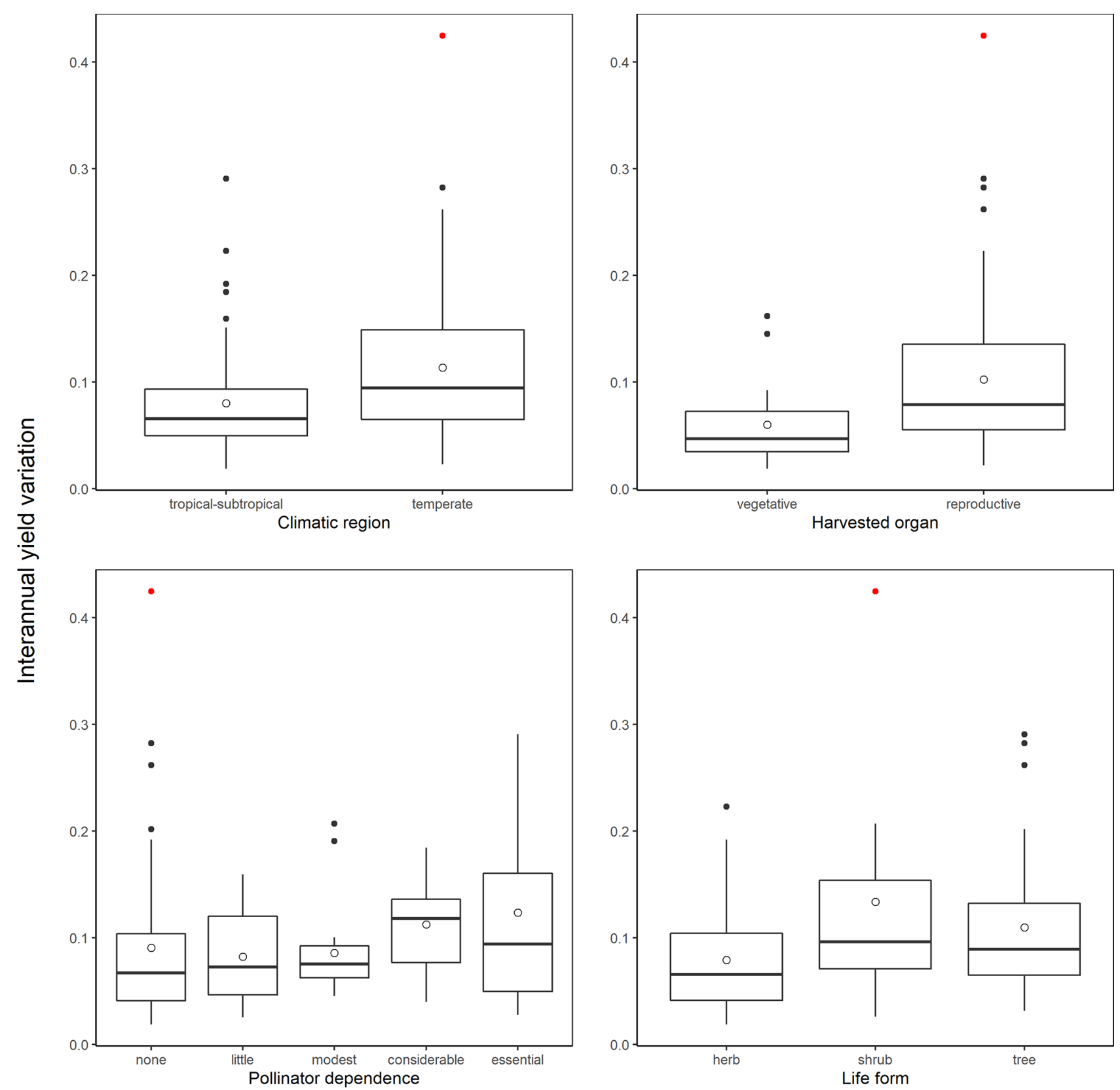

Figure A2. Boxplots showing the distribution of the interannual yield variation against climatic region, type of harvested organ, pollinator dependence, and crop life form. Boxes delimit the lower and upper quartiles; the black horizontal line within the boxes shows the median, the white circle the mean, the vertical lines the whiskers, and the points outside the boxes the outlying points. The red outlying points correspond to the FAO item "jojoba seeds". 


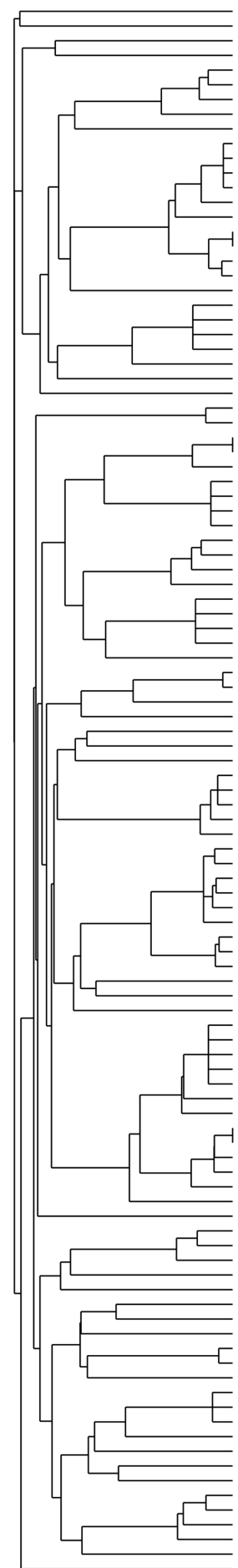

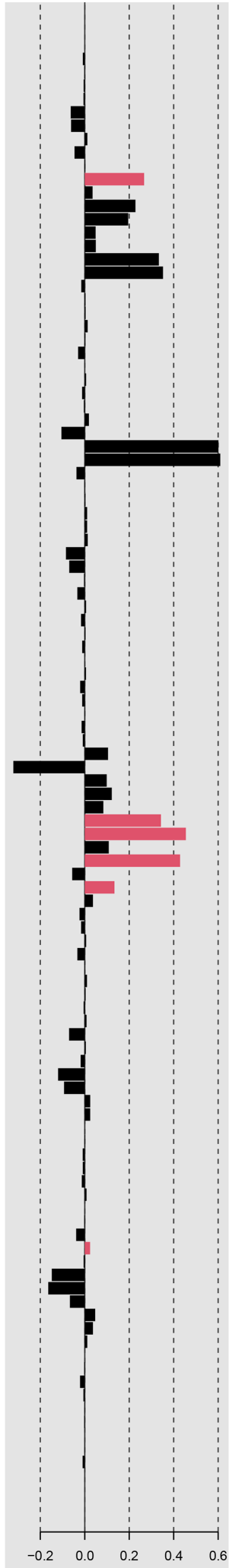

(a)

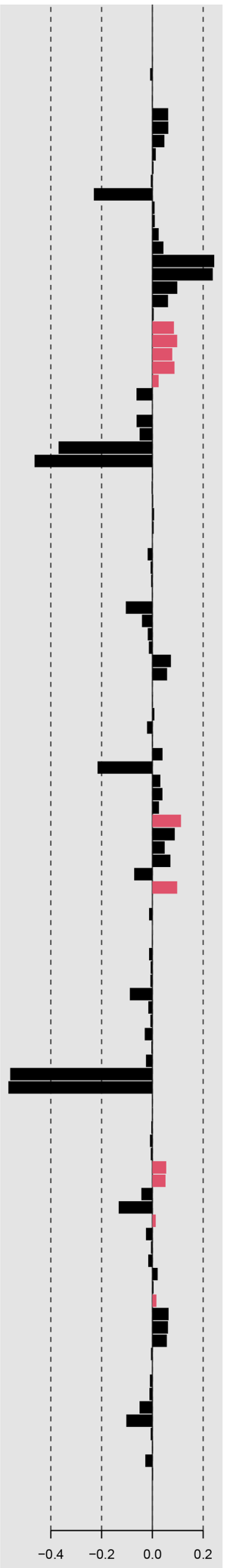

(b) pepper

avocados
yautia

aro

coconuts
palm fruit oil

areca nuts

dates

bananas

Wheat

rye

barley
oats

rice
green maize

green maize
maize

sugar can

sorghum

pineapples

green onions a

dry onions
leeks

garlic

asparagus

vanilla

yams
gooseberries
currants

cashew apples

cashew nuts

pistachios

mandarins

oranges

grapefruits

grapefruits

seed cotton

kola nuts

rapeseed

cauliflowers and broccol

cabbages

cassava leaves

castor oil seeds

linseed

walnuts

chestnuts

cucumbers and gherkins

melonseed

melons and cantaloupes

pumpkins, squash, and gourds

sour cherries

apricots

plums and sloes
peaches and nectarines

peaches and

quinces

apples

pears

berries
strawberries

ftrawberries

string beans
cowpeas

green bean

dry beans

Bambara beans

on peas

green peas

dry peas

lentils

groundnuts

grapes

spinach

suinoar beet

buckwheat

Brazil nuts

karite nuts

karite nuts

cranberries

kiwi

tomatoes

eggplants

sweet potatoes

coffee

sesame seeds
sesam

sunflower seeds

sunflower seeds

carrots

Figure A3. Local indicators of phylogenetic association (LIPA) scores for (a) $\Delta$ yield and (b) SD( $\Delta$ yield), depicted with a bar for each crop. Significant values $(p<0.05)$ are indicated with colored bars. 


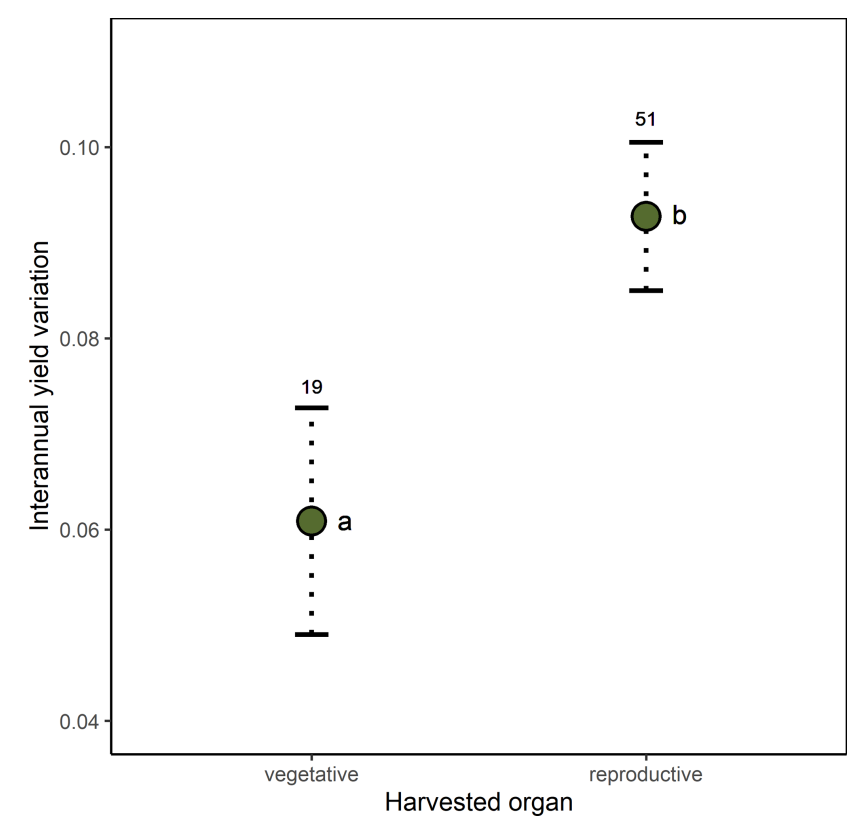

Figure A4. Effect of type of harvested organ on interannual yield variation, $\mathrm{SD}(\Delta$ yield), for herbaceous and shrubby crops. Modeladjusted estimated means are illustrated with points and standard errors with dotted lines. Sample sizes are shown for each category. Significant differences are indicated with different letters (see Table A4). 
Data availability. The data used in this study can be obtained from sources cited in the main text and also from Appendix A.

Author contributions. GG and MAA conceived the study and designed the methodology; GG analyzed the data; GG and MAA wrote the original manuscript; AS, GG, NLdC, and MAA contributed substantially to the final manuscript.

Competing interests. The authors declare that they have no conflict of interest.

Acknowledgements. The authors thank Rubén Milla for providing very helpful comments on a previous version of this paper and acknowledge the support of the SURPASS2 project funded under the Newton Fund Latin America Biodiversity Programme: Biodiversity - Ecosystem services for sustainable development grants awarded by the Natural Environment Research Council of Great Britain (NERC; grant no. NE/S011870/1), the National Scientific and Technical Research Council of Argentina (CONICET; grant no. RD 1984/19), and the National Fund for Scientific and Technological Research of Argentina (FONCYT; grant nos. PICT 2015-2333, PICT 2018-2145, and PICT-2018-03559).

Review statement. This paper was edited by Daniel Montesinos and reviewed by Rubén Milla and one anonymous referee.

\section{References}

Aizen, M. A. and Harder, L. D.: The global stock of domesticated honey bees is growing slower than agricultural demand for pollination, Curr. Biol., 19, 915-918, https://doi.org/10.1016/j.cub.2009.03.071, 2009.

Aizen, M. A., Garibaldi, L. A., Cunningham, S. A., and Klein, A. M.: Long-term global trends in crop yield and production reveal no current pollination shortage but increasing pollinator dependency, Curr. Biol., 18, 1572-1575, https://doi.org/10.1016/j.cub.2008.08.066, 2008.

Aizen, M. A., Aguiar, S., Biesmeijer, J. C., Garibaldi, L. A., Inouye, D. W., Jung, C., Martins, D. J., Medel, R., Morales, C. L., Ngo, H., Pauw, A., Paxton, R. J., Sáez, A., and Seymour, C. L.: Global agricultural productivity is threatened by increasing pollinator dependence without a parallel increase in crop diversification, Glob. Change Biol., 25, 3516-3527, https://doi.org/10.1111/gcb.14736, 2019.

Al-Obaidi, J. R., Farouq Halabi, M., AlKhalifah, N. S., Asanar, S., Al-Soqeer, A. A., and Attia, M. F.: A review on plant importance, biotechnological aspects, and cultivation challenges of jojoba plant, Biol. Res., 50, 25, https://doi.org/10.1186/s40659017-0131-x, 2017.

Angiosperm Phylogeny Group, Chase, M. W., Christenhusz, M. J. M., Fay, M. F., Byng, J. W., Judd, W. S., Soltis, D. E., Mabberley, D. J., Sennikov, A. N., Soltis, P. S., and Stevens, P. F.: An update of the Angiosperm Phylogeny Group classification for the orders and families of flowering plants: APG IV, Bot. J. Linn. Soc., 181, 1-20, https://doi.org/10.1111/boj.12385, 2016.

Anselin, L.: Local indicators of spatial association - LISA, Geograph. Analysis, 27, 93-115, https://doi.org/10.1111/j.15384632.1995.tb00338.x, 1995.

Arditti, J., Rao, A. N., and Nair, H.: History pollination, in: Orchid Biology: Reviews and Perspectives, X, edited by: Kull, T., Arditti, J., and Wong, S. M., Springer, Dordrecht, The Netherlands, 233-249, https://doi.org/10.1007/978-1-4020-8802-5_7, 2009.

Arias, T., Beilstein, M. A., Tang, M., McKain, M. R., and Pires, J. C.: Diversification times among Brassica (Brassicaceae) crops suggest hybrid formation after 20 million years of divergence, Am. J. Bot., 101, 86-91, https://doi.org/10.3732/ajb.1300312, 2014.

Bauer, D. M. and Wing, I. S.: The macroeconomic cost of catastrophic pollinator declines, Ecol. Econ., 126, 1-13, https://doi.org/10.1016/j.ecolecon.2016.01.011, 2016.

Bedigian, D., Seigler, D. S., and Harlan, J. R.: Sesamin, sesamolin and the origin of sesame, Biochem. Syst. Ecol., 13, 133-139, https://doi.org/10.1016/0305-1978(85)90071-7, 1985.

Blomberg, S. P., Garland, T., and Ives, A. R.: Testing for phylogenetic signal in comparative data: behavioral traits are more labile, Evolution, 57, 717-745, https://doi.org/10.1111/j.00143820.2003.tb00285.x, 2003.

Bogdziewicz, M., Żywiec, M., Espelta, J. M., FernándezMartinez, M., Calama, R., Ledwoń, M., McIntire, E., and Crone, E. E.: Environmental veto synchronizes mast seeding in four contrasting tree species, Am. Nat., 194, 246-259, https://doi.org/10.1086/704111, 2019.

Bommarco, R., Kleijn, D., and Potts, S. G.: Ecological intensification: harnessing ecosystem services for food security, Trends Ecol. Evol., 28, 230-238, https://doi.org/10.1016/j.tree.2012.10.012, 2013.

Brittain, C., Kremen, C., Garber, A., and Klein, A.-M.: Pollination and plant resources change the nutritional quality of almonds for human health, PLoS ONE, 9, e90082, https://doi.org/10.1371/journal.pone.0090082, 2014.

Brown, J. and Cunningham, S. A.: Global-scale drivers of crop visitor diversity and the historical development of agriculture, P. Roy. Soc. B-Biol. Sci., 286, 20192096, https://doi.org/10.1098/rspb.2019.2096, 2019.

Caracuta, V., Weinstein-Evron, M., Kaufman, D., Yeshurun, R., Silvent, J., and Boaretto, E.: 14,000-year-old seeds indicate the Levantine origin of the lost progenitor of faba bean, Sci. Rep.-UK., 6, 37399, https://doi.org/10.1038/srep37399, 2016.

Challinor, A. J., Watson, J., Lobell, D. B., Howden, S. M., Smith, D. R., and Chhetri, N.: A meta-analysis of crop yield under climate change and adaptation, Nat. Clim. Change, 4, 287-291, https://doi.org/10.1038/nclimate2153, 2014.

Cheplick, G. P.: The allometry of reproductive allocation, in: Reproductive allocation in plants, edited by: Reekie, E. G. and Bazzaz, F. A., Elsevier Academic Press, Burlington, USA, 97-128, 2005.

Chomicki, G. and Renner, S. S.: Watermelon origin solved with molecular phylogenetics including Linnaean material: another example of museomics, New Phytol., 205, 526-532, https://doi.org/10.1111/nph.13163, 2015.

Decroocq, S., Cornille, A., Tricon, D., Babayeva, S., Chague, A., Eyquard, J.-P., Karychev, R., Dolgikh, S., Kostritsyna, T., 
Liu, S., Liu, W., Geng, W., Liao, K., Asma, B. M., Akparov, Z., Giraud, T., and Decroocq, V.: New insights into the history of domesticated and wild apricots and its contribution to Plum pox virus resistance, Mol. Ecol., 25, 4712-4729, https://doi.org/10.1111/mec.13772, 2016.

Eilers, E. J., Kremen, C., Greenleaf, S. S., Garber, A. K., and Klein, A. M.: Contribution of pollinator-mediated crops to nutrients in the human food supply, PLoS ONE, 6, e21363, https://doi.org/10.1371/journal.pone.0021363, 2011.

Evenson, R. E. and Gollin, D.: Assessing the impact of the green revolution, 1960 to 2000, Science, 300, 758-762, https://doi.org/10.1126/science.1078710, 2003.

FAOSTAT: Food and Agriculture Organization Corporate Statistical Database, available at: http://www.fao.org/faostat/en (last access: 18 November 2020), 2019.

Faust, M. and Timon, B.: Origin and dissemination of peach, Horticultural Reviews 17, 331-379, https://doi.org/10.1002/9780470650585.ch10, 1995.

Felsenstein, J.: Phylogenies and the comparative method, Am. Nat., 125, 1-15, https://doi.org/10.1086/284325, 1985.

Foley, J. A., Ramankutty, N., Brauman, K. A., Cassidy, E. S., Gerber, J. S., Johnston, M., Mueller, N. D., O'Connell, C., Ray, D. K., West, P. C., Balzer, C., Bennett, E. M., Carpenter, S. R., Hill, J., Monfreda, C., Polasky, S., Rockström, J., Sheehan, J., Siebert, S., Tilman, D., and Zaks, D. P. M.: Solutions for a cultivated planet, Nature, 478, 337-342, https://doi.org/10.1038/nature10452, 2011.

Fox, J. and Weisberg, S.: An R Companion to Applied Regression, 3rd Edition, Thousand Oaks, CA, USA, 2019.

Gallai, N., Salles, J. M., Settele, J., and Vaissière, B. E.: Economic valuation of the vulnerability of world agriculture confronted with pollinator decline, Ecol. Econ., 68, 810-821, https://doi.org/10.1016/j.ecolecon.2008.06.014, 2009.

Garibaldi, L. A., Aizen, M. A., Cunningham, S., and Klein, A. M.: Pollinator shortage and global crop yield: looking at the whole spectrum of pollinator dependency, Commun. Integr. Biol., 2, 37-39, https://doi.org/10.4161/cib.2.1.7425, 2009.

Garibaldi, L. A., Aizen, M. A., Klein, A. M., Cunningham, S. A., and Harder, L. D.: Global growth and stability of agricultural yield decrease with pollinator dependence, P. Natl. Acad. Sci.-Biol., 108, 5909-5914, https://doi.org/10.1073/pnas.1012431108, 2011.

Garibaldi, L. A., Steffan-Dewenter, I., Winfree, R., Aizen, M. A., Bommarco, R., Cunningham, S. A., Kremen, C., Carvalheiro, L. G., Harder, L. D., Afik, O., Bartomeus, I., Benjamin, F., Boreux, V., Cariveau, D., Chacoff, N. P., Dudenhöffer, J. H., Freitas, B. M., Ghazoul, J., Greenleaf, S., Hipólito, J., Holzschuh, A., Howlett, B., Isaacs, R., Javorek, S. K., Kennedy, C. M., Krewenka, K. M., Krishnan, S., Mandelik, Y., Mayfield, M. M., Motzke, I., Munyuli, T., Nault, B. A., Otieno, M., Petersen, J., Pisanty, G., Potts, S. G., Rader, R., Ricketts, T. H., Rundlöf, M., Seymour, C. L., Schüepp, C., Szentgyörgyi, H., Taki, H., Tscharntke, T., Vergara, C. H., Viana, B. F., Wanger, T. C., Westphal, C., Williams, N., and Klein, A. M: Wild pollinators enhance fruit set of crops regardless of honey bee abundance, Science, 339, 1608-1611, https://doi.org/10.1126/science.1230200, 2013.

Garibaldi, L. A., Carvalheiro, L. G., Leonhardt, S. D., Aizen, M. A., Blaauw, B. R., Isaacs, R., Kuhlmann, M., Kleijn, D., Klein, A. M., Kremen, C., Morandin, L., Scheper, J., and Winfree,
R.: From research to action: practices to enhance crop yield through wild pollinators, Front. Ecol. Environ., 12, 439-447, https://doi.org/10.1890/130330, 2014.

Garibaldi, L. A., Sáez, A., Aizen, M. A., Fijen, T., and Bartomeus, I: Crop pollination management needs flower-visitor monitoring and target values, J. Appl. Ecol., 57, 664-670, https://doi.org/10.1111/1365-2664.13574, 2020.

Godfray, H. C. J., Beddington, J. R., Crute, I. R., Haddad, L., Lawrence, D., Muir, J. F., Pretty, J., Robinson, S., Thomas, S. M., and Toulmin, C.: Food security: the challenge of feeding 9 billion people, Science, 327, 812-818, https://doi.org/10.1126/science.1185383, 2010.

Gondola, I. and Papp, P. P.: Origin, geographical distribution and phylogenetic relationships of common buckwheat (Fagopyrum esculentum Moench), Eur. J. Plant Sci. Biotechnol., 4,17-32, 2010.

Guo, D., Zhang, H., and Luo, Z.: Genetic relationships of Diospyros kaki Thunb and related species revealed by IRAP and REMAP analysis, Plant Sci., 170, 528-533, https://doi.org/10.1016/j.plantsci.2005.10.006, 2006.

Guo, J., Wang, Y., Song, C., Zhou, J., Qiu, L., Huang, H., and Wang, Y.: A single origin and moderate bottleneck during domestication of soybean (Glycine max): implications from microsatellites and nucleotide sequences, Ann. Bot., 106, 505-514, https://doi.org/10.1093/aob/mcq125, 2010.

Harper, J. L.: Population biology of plants, Academic Press, London, UK, 1977.

Harris, S. A., Robinson, J. P., and Juniper, B. E: Genetic clues to the origin of the apple, Trends Genet., 18, 426-430, https://doi.org/10.1016/S0168-9525(02)02689-6, 2002.

Hatfield, J. L. and Walthall, C. L.: Meeting global food needs: realizing the potential via genetics $\mathrm{x}$ environment $\mathrm{x}$ management interactions, Agron. J., 107, 1215-1226, https://doi.org/10.2134/agronj15.0076, 2015.

Herrera, C. M.: Variation in mutualisms: the spatiotemporal mosaic of a pollinator assemblage, Biol. J. Linn. Soc., 35, 95-125, https://doi.org/10.1111/j.1095-8312.1988.tb00461.x, 1988.

Hirschegger, P., Jakse, J., Trontelj, P., and Bohanec, B.: Origins of Allium ampeloprasum horticultural groups and a molecular phylogeny of the section Allium (Allium: Alliaceae), Mol. Phylogenet. Evol., 54, 488-497, https://doi.org/10.1016/j.ympev.2009.08.030, 2010.

Horvitz, C. C. and Schemske, D. W.: Spatiotemporal variation in insect mutualists of a neotropical herb, Ecology, 71, 1085-1097, https://doi.org/10.2307/1937377, 1990.

Horvitz C. C. and Schemske, D. W.: Effects of plant size, leaf herbivory, local competition and fruit production on survival, growth and future reproduction of a neotropical herb, J. Ecol., 90, 279290, https://doi.org/10.1046/j.1365-2745.2001.00660.x, 2002.

Hulshof, C. M., Stegen, J. C., Swenson, N. G., Enquist, C. A. F., and Enquist, B. J.: Interannual variability of growth and reproduction in Bursera simaruba: the role of allometry and resource variability, Ecology, 93, 180-190, https://doi.org/10.1890/110740.1, 2012.

Iizumi, T., Yokozawa, M., Sakurai, G., Travasso, M. I., Romanenkov, V., Oettli, P., Newby, T., Ishigooka, Y., and Furuya, J: Historical changes in global yields: major cereal and legume crops from 1982 to 2006, Global Ecol. Biogeog., 23, 346-357, https://doi.org/10.1111/geb.12120, 2014. 
Jeffery S., Avalos, D., Prodana, M., Bastos, A. C., van Groenigen, J. W., Hungate, B. A., and Verheijen, F.: Biochar boosts tropical but not temperate crop yields, Environ. Res. Lett., 12, 053001, https://doi.org/10.1088/1748-9326/aa67bd, 2017.

Jensen, J. L. W.: Sur les fonctions convexes et les inégalités entre les valeurs moyennes, Acta Math., 30, 175-193, 1906.

Jin, Y. and Qian, H.: V.PhyloMaker: an R package that can generate very large phylogenies for vascular plants, Ecography, 42, 1-7, https://doi.org/10.1111/ecog.04434, 2019.

Kantar, M. B., Sosa, C. C., Khoury, C. K., Castañeda-Álvarez, N. P., Achicanoy, H. A., Bernau, V., Kane, N. C., Marek, L., Seiler, G., and Rieseberg, L. H.: Ecogeography and utility to plant breeding of the crop wild relatives of sunflower (Helianthus annuus L.), Front. Plant Sci., 6, 841, https://doi.org/10.3389/fpls.2015.00841, 2015.

Keck, F., Rimet, F., Bouchez, A., and Franc, A.: phylosignal: an R package to measure, test, and explore the phylogenetic signal, Ecol. Evol., 6, 2774-2780, https://doi.org/10.1002/ece3.2051, 2016.

Kho, R. M.: On crop production and the balance of available resources, Agr. Ecosyst. Environ., 80, 71-85, https://doi.org/10.1016/S0167-8809(00)00135-3, 2000.

Khoury, C. K., Achicanoy, H. A., Bjorkman, A. D., NavarroRacines, C., Guarino, L., Flores-Palacios, X., Engels, J. M. M., Wiersema, J. H., Dempewolf, H., Sotelo, S., Ramírez-Villegas, J., Castañeda-Alvarez, N. P., Fowler, C., Jarvis, A., Rieseberg, L. H., and Struik, P. C.: Origins of food crops connect countries worldwide, P. Roy. Soc. B-Biol. Sci., 283, 20160792 , https://doi.org/10.1098/rspb.2016.0792, 2016.

Klein, A.-M., Vaissière, B. E., Cane, J. H., Steffan-Dewenter, I., Cunningham, S. A., Kremen, C., and Tscharntke, T.: Importance of pollinators in changing landscapes for world crops, P. Roy. Soc. B-Biol. Sci., 274, 303-313, https://doi.org/10.1098/rspb.2006.3721, 2007.

Knight, T. M., Steets, J. A., Vamosi, J. C., Mazer, S. J., Burd, M., Campbell, D. R., Dudash, M. R., Johnston, M. O., Mitchell, R. J., and Ashman, T.-L.: Pollen limitation in plant reproduction: pattern and process, Annu. Rev. Ecol. Evol. S., 36, 467497, https://doi.org/10.1146/annurev.ecolsys.36.102403.115320, 2005.

Kozlowski J. and Uchmanski, J.: Optimal individual growth and reproduction in perennial species with indeterminate growth, Evol. Ecol., 1, 214-230, https://doi.org/10.1007/BF02067552, 1987.

Kramer, P. J.: Crop reactions to water and temperature stresses in humid, temperate climates, CRC Press, Boca Ratón, USA, 2019.

Kř́ístková, E., Doležalová, I., Lebeda, A., Vinter, V., and Novotná, A.: Description of morphological characters of lettuce (Lactuca sativa L.) genetic resources, Hort. Sci., 35, 113-129, https://doi.org/10.17221/4/2008-HORTSCI, 2008.

Kucharik, C. J., Ramiadantsoa, T., Zhang, J., and Ives, A. R.: Spatiotemporal trends in crop yields, yield variability, and yield gaps across the USA, Crop Sci., https://doi.org/10.1002/csc2.20089, in press, 2020.

Kumar, S., Mangal, M., Dhawan, A. K., and Singh, N.: Assessment of genetic fidelity of micropropagated plants of Simmondsia chinensis (Link) Schneider using RAPD and ISSR markers, Acta Physiol. Plant., 33, 2541-2545, https://doi.org/10.1007/s11738011-0767-z, 2012.
Lacey, E. P.: Onset of reproduction in plants: sizevs age-dependency, Trends Ecol. Evol., 3, 72-75, https://doi.org/10.1016/0169-5347(86)90021-2, 1986.

Leff, B., Ramankutty, N., and Foley, J. A.: Geographic distribution of major crops across the world, Global Biogeochem. Cy., 18, GB1009, https://doi.org/10.1029/2003GB002108, 2004.

Li, D., Trotta, L., Marx, H. E., Allen, J. M., Sun, M., Soltis, D. E., Soltis, P. S., Guralnick, R. P., and Baiser, B.: For common community phylogenetic analyses, go ahead and use synthesis phylogenies, Ecology, 100, e02788, https://doi.org/10.1002/ecy.2788, 2019.

Martin, A. R., Cadotte, M. W., Isaac, M. E., Milla, R., Vile, D., and Violle, C.: Regional and global shifts in crop diversity through the Anthropocene, PLoS ONE, 14, e0209788, https://doi.org/10.1371/journal.pone.0209788, 2019.

Mazer, S. J.: Ecological, taxonomic, and life history correlates of seed mass among Indiana dune angiosperms, Ecol. Monogr., 59, 153-175, https://doi.org/10.2307/2937284, 1989.

Miflin, B.: Crop improvement in the 21 st century, J. Exp. Bot., 51, 1-8, https://doi.org/10.1093/jexbot/51.342.1, 2000.

Milla, R.: Crop Origins and Phylo Food: A database and a phylogenetic tree to stimulate comparative analyses on the origins of food crops, Global Ecol. Biogeog., 29, 606-614, https://doi.org/10.1111/geb.13057, 2020.

Milla, R., Osborne, C. P., Turcotte, M. M., and Violle, C.: Plant domestication through an ecological lens, Trends Ecol. Evol., 30, 463-469, https://doi.org/10.1016/j.tree.2015.06.006, 2015.

Milla, R., Bastida, J. M., Turcotte, M. M., Jones, G., Violle, C., Osborne, C. P., Chacón-Labella, J., Sosinski, Ê. E., Kattge, J., Laughlin, D. C., Forey, E., Minden, V., Cornelissen, J. H. C., Amiaud, B., Kramer, K., Boenisch, G., He, T., Pillar, V. D., and Byun, C.: Phylogenetic patterns and phenotypic profiles of the species of plants and mammals farmed for food, Nat. Ecol. Evol., 2, 1808-1817, https://doi.org/10.1038/s41559-018-06904, 2018.

Obeso, J. R.: The costs of reproduction in plants, New Phytol., 155, 321-348, https://doi.org/10.1046/j.1469-8137.2002.00477.x, 2002.

Paradis, E.: Analysis of phylogenetics and evolution with R, 2nd edition, Springer, New York, USA, 2012.

Paradis, E. and Schliep, K.: ape 5.0: and environment for modern phylogenetics and evolutionary analyses in R, Bioinformatics, 35, 526-528, https://doi.org/10.1093/bioinformatics/bty633, 2019.

Partap, U. M. A. and Ya, T.: The human pollinators of fruit crops in Maoxian County, Sichuan, China, Mt. Res. Dev., 32, 176-186, https://doi.org/10.1659/MRD-JOURNAL-D-11-00108.1, 2012.

Partap, U. M. A., Partap, T. E. J., and Yonghua, H. E.: Pollination failure in apple crop and farmers' management strategies in Hengduan mountains, China, Acta Hortic., 561, 225-230, https://doi.org/10.17660/ActaHortic.2001.561.32, 2001.

Pearse, I. S., Koenig, W. D., and Kelly, D.: Mechanisms of mast seeding: resources, weather, cues, and selection, New Phytol., 212, 546-562, https://doi.org/10.1111/nph.14114, 2016.

Petit, R. J. and Hampe, A.: Some evolutionary consequences of being a tree, Annu. Rev. Ecol. Evol. S., 37, 187214, https://doi.org/10.1146/annurev.ecolsys.37.091305.110215, 2006. 
Pinheiro, J., Bates, D., DebRoy, S., Sarkar, D., and the R Core Team: nlme: linear and nonlinear mixed effects models, R package version 3.1-140, 2019.

Potts, S. G., Biesmeijer, J. C., Kremen, C., Neumann, P., Schweiger, O., and Kunin, W. E.: Global pollinator declines: Trends, impacts and drivers, Trends Ecol. Evol., 25, 345-353, https://doi.org/10.1016/j.tree.2010.01.007, 2010.

Price, M. V., Waser, N. M., Irwin, R. E., Campbell, D. R., and Brody, A. K.: Temporal and spatial variation in pollination of a montane herb: a seven-year study, Ecology, 86, 2106-2116, https://doi.org/10.1890/04-1274, 2005.

Rabeling, S. C., Lim, J. L., Tidon, R., Neff, J. L., Simpson, B. B., and Pawar, S.: Seasonal variation of a plantpollinator network in the Brazilian Cerrado: Implications for community structure and robustness, PLoS ONE, 14, e0224997, https://doi.org/10.1371/journal.pone.0224997, 2019.

Rader, R., Bartomeus, I., Garibaldi, L. A., Garratt, M. P. D., Howlett, B. G., Winfree, R., Cunningham, S. A., Mayfield, M. M., Arthur, A. D, Andersson, G. K. S., Bommarco, R., Brittain, C., Carvalheiro, L. G., Chacoff, N. P., Entling, M. H., Foully, B., Freitas, B. M., Gemmill-Herren, B., Ghazoul, J., Griffin, S. R., Gross, C. L., Herbertsson, L., Herzog, F., Hipólito, J., Jaggar, S., Jauker, F., Klein, A.-M., Kleijn, D., Krishnan, S., Lemos, C. Q., Lindström, S. A. M., Mandelik, Y., Monteiro, V. M., Nelson, W., Nilsson, L., Pattemore, D. E., de Pereira, N. O., Pisanty, G., Potts, S. G., Reemer, M., Rundlöf, M., Sheffield, C. S., Scheper, J., Schüepp, C., Smith, H. G., Stanley, D. A., Stout, J. C., Szentgyörgyi, H., Taki, H., Vergara, C. H., Viana, B. F., and Woyciechowski, M.: Non-bee insects are important contributors to global crop pollination, P. Natl. Acad. Sci.-Biol., 113, 146-151, https://doi.org/10.1073/pnas.1517092112, 2016.

Ray, D. K., Ramankutty, N., Mueller, N. D., West, P. C., and Foley, J. A.: Recent patterns of crop yield growth and stagnation, Nat. Commun., 3, 1293, https://doi.org/10.1038/ncomms2296, 2012.

Ray, D. K., Gerber, J. S., MacDonald, G. K., and West, P. C.: Climate variation explains a third of global crop yield variability, Nat. Commun., 6, 5989, https://doi.org/10.1038/ncomms6989, 2015.

Revell, L. J.: Phylogenetic signal and linear regression on species data, Methods Ecol. Evol., 1, 319-329, https://doi.org/10.1111/j.2041-210X.2010.00044.x, 2010.

Revell, L. J.: phytools: An R package for phylogenetic comparative biology (and other things), Methods Ecol. Evol., 3, 217-223, https://doi.org/10.1111/j.2041-210X.2011.00169.x, 2012.

Rodrigo, J.: Spring frosts in deciduous fruit trees - morphological damage and flower hardiness, Sci. Hortic-Amsterdam, 85, 155173, https://doi.org/10.1016/S0304-4238(99)00150-8, 2000.

Rosenzweig, C. and Liverman, D.: Predicted effects of climate change on agriculture: A comparison of temperate and tropical regions, in: Global climate change: Implications, challenges, and mitigation measures, edited by: Majumdar, S. K., The Pennsylvania Academy of Sciences, Easton, USA, 342-361, 1992.

Ruel, J. J. and Ayres, M. P.: Jensen's inequality predicts effects of environmental variation, Trends Ecol. Evol., 14, 361-366, https://doi.org/10.1016/S0169-5347(99)01664-X, 1999.

Sáez, A., Negri, P., Viel, M., and Aizen, M. A: Pollination efficiency of artificial and bee pollination practices in kiwifruit, Sci. Hortic-Amsterdam, 246, 1017-1021, https://doi.org/10.1016/j.scienta.2018.11.072, 2019.
Sanjur, O. I., Piperno, D. R., Andres, T. C., and WesselBeaver, L.: Phylogenetic relationships among domesticated and wild species of Cucurbita (Cucurbitaceae) inferred from a mitochondrial gene: Implications for crop plant evolution and areas of origin, P. Natl. Acad. Sci.-Biol., 99, 535-540, https://doi.org/10.1073/pnas.012577299, 2002.

Santiago, L. S.: Nutrient limitation of eco-physiological processes in tropical trees, Trees, 29, 1291-1300, https://doi.org/10.1007/s00468-015-1260-x, 2015.

Schauberger, B., Rolinski, S., and Müller, C.: A network-based approach for semi-quantitative knowledge mining and its application to yield variability, Environ. Res. Lett., 11, 123001, https://doi.org/10.1088/1748-9326/11/12/123001, 2016.

Schulze, E.-D., Beck, E., Buchmann, N., Clemens, S., MüllerHohenstein, K., and Scherer-Lorenzen, M.: Plant Ecology, Second Edition, Springer, Berlin and Heidelberg, Germany, https://doi.org/10.1007/978-3-662-56233-8, 2019.

Sebastian, P., Schaefer, H., Telford, I. R. H., and Renner, S. S.: Cucumber (Cucumis sativus) and melon (C. melo) have numerous wild relatives in Asia and Australia, and the sister species of melon is from Australia, P. Natl. Acad. Sci.-Biol., 107, 269-273, https://doi.org/10.1073/pnas.1005338107, 2010.

Slot, M. and Winter, K.: In situ temperature response of photosynthesis of 42 tree and liana species in the canopy of two Panamanian lowland tropical forests with contrasting rainfall regimes, New Phytol., 214, 1103-1117, https://doi.org/10.1111/nph.14469, 2017.

Smith, H. M. and Samach, A.: Constraints to obtaining consistent annual yields in perennial tree crops. I: Heavy fruit load dominates over vegetative growth, Plant Sci., 207, 158-167, https://doi.org/10.1016/j.plantsci.2013.02.014, 2013.

Snyder, R. L. and de Melo-Abreu, J. P.: Frost Protection: fundamentals, practice and economics, Volume 1., Food and Agriculture Organization of the United Nations, FAO, Rome, Italy, 2005.

Soriano, J. M., Pecchioli, S., Romero, C., Vilanova, S., Llácer, G., Giordani, E., and Badenes, M. L.: Development of microsatellite markers in polyploidy persimmon (Diospyros kaki Lf) from an enriched genomic library, Mol. Ecol. Notes, 6, 368-370, https://doi.org/10.1111/j.1471-8286.2006.01236.x, 2006.

Souza, C. S., Maruyama, P. K., Aoki, C., Sigrist, M. R., Raizer, J., Gross, C. L., and de Araujo, A. C.: Temporal variation in plantpollinator networks from seasonal tropical environments: Higher specialization when resources are scarce, J. Ecol., 106, 24092420, https://doi.org/10.1111/1365-2745.12978, 2018.

Symonds, M. R. and Blomberg, S. P.: A primer on phylogenetic generalised least squares, in: Modern phylogenetic comparative methods and their application in evolutionary biology, edited by: Garamszegi, L. Z., 105-130, Springer, Heidelberg, Germany, https://doi.org/10.1007/978-3-662-43550-2, 2014.

Tan, S., Yang, Y., and Huang, W.: Moderate heat stress accelerates photoinhibition of photosystem I under fluctuating light in tobacco young leaves, Photosynth. Res., 144, 373-382, https://doi.org/10.1007/s11120-020-00754-7, 2020.

Teteni, P.: Biodiversity of Papaver somniferum L. (opium poppy), Acta Hortic., 390, 191-201, https://doi.org/10.17660/ActaHortic.1995.390.27, 1995.

Tilman, D.: Global environmental impacts of agricultural expansion: the need for sustainable and efficient 
practices, P. Natl. Acad. Sci.-Biol., 96, 5995-6000, https://doi.org/10.1073/pnas.96.11.5995, 1999.

Tilman, D., Cassman, K. G., Matson, P. A., Naylor, R., and Polasky, S.: Agricultural sustainability and intensive production practices, Nature, 418, 671-677, https://doi.org/10.1038/nature01014, 2002.

Toffolatti, S. L., De Lorenzis, G., Costa, A., Maddalena, G., Passera, A., Bonza, M. C., Pindo, M., Stefani, E., Cestaro, A., Casati, P., Failla, O., Bianco, P. A., Maghradze, D., and Quaglino, F.: Unique resistance traits against downy mildew from the center of origin of grapevine (Vitis vinifera), Sci. Rep.-UK, 8, 12523, https://doi.org/10.1038/s41598-018-30413-w, 2018.

Tuller, J., Marquis, R. J., Andrade, S. M. M., Monteiro, A. B., and Faria, L. D. B.: Trade-offs between growth, reproduction and defense in response to resource availability manipulations, PLoS ONE, 13, 1-12, https://doi.org/10.1371/journal.pone.0201873, 2018.

van der Vossen, H. A. M. and Mkamilo, G. S. (Eds.): Plant resources of tropical Africa 14, Vegetable Oils, PROTA Foundation, Wageningen, the Netherlands, 2007.

Wang, L., He, F., Huang, Y., He, J., Yang, S., Zeng, J., Deng, C., Jiang, X., Fang, Y., Wen, S., Xu, R., Yu, H., Yang, X., Zhong, G., Chen, C., Yan, X., Zhou, C., Zhang, H., Xie, Z., Larkin, R. M., Deng, X., and Xu, Q.: Genome of wild mandarin and domestication history of mandarin, Mol. Plant, 11, 1024-1037, https://doi.org/10.1016/j.molp.2018.06.001, 2018.

Weiner, J., Campbell, L. G., Pino, J., and Echarte, L.: The allometry of reproduction within plant populations, J. Ecol., 97, 12201233, https://doi.org/10.1111/j.1365-2745.2009.01559.x, 2009.
West, B. T., Welch, K. B., and Galecki, A. T.: Linear Mixed Models: A Practical Guide Using Statistical Software, Chapman and Hall/CRC, Boca Raton, FL, USA, 2007.

Willmer, P.: Pollination and floral ecology, Princeton University Press, Princeton, New Jersey, USA, 2011.

Wu, G. A., Terol, J., Ibanez, V., López-García, A., Pérez-Roman, E., Borreda, C., Domingo, C., Tadeo, F. R., Carbonell-Caballero, J., Alonso, R., Curk, F., Du, D., Ollitrault, P., Roose, M. L., Dopazo, J., Gmitter, F. G., Rokhsar, D. S., and Talon, M.: Genomics of the origin and evolution of Citrus, Nature, 554, 311316, https://doi.org/10.1038/nature25447, 2018.

Zeinalabedini, M., Khayam-Nekoui, M., Grigorian, V., Gradziel, T. M., Martínez-Gómez, P.: The origin and dissemination of the cultivated almond as determined by nuclear and chloroplast SSR marker analysis, Sci. Hortic-Amsterdam, 125, 593-601, https://doi.org/10.1016/j.scienta.2010.05.007, 2010.

Zhao, C., Liu, B., Piao, S., Wang, X., Lobell, D. B., Huang, Y., Huang, M., Yao, Y., Bassu, S., Ciais, P., Durand, J.-L., Elliott, J., Ewert, F., Janssens, I. A., Li, T., Lin, E., Liu, Q., Martre, P., Müller, C., Peng, S., Peñuelas, J., Ruane, A. C., Wallach, D., Wang, T., Wu, D., Liu, Z., Zhu, Y., Zhu, Z., and Asseng, S.: Temperature increase reduces global yields of major crops in four independent estimates, P. Natl. Acad. Sci.-Biol., 114, 9326-9331, https://doi.org/10.1073/pnas.1701762114, 2017.

Zheng, L., Ives, A. R., Garland Jr, T., Larget, B. R., Yu, Y., and Cao, K.: New multivariate tests for phylogenetic signal and trait correlations applied to ecophysiological phenotypes of nine Manglietia species, Funct. Ecol., 23,1059-1069, https://doi.org/10.1111/j.1365-2435.2009.01596.x, 2009. 